УДК 551.7.001.5(4'7) (470.53)

\title{
СТРОЕНИЕ И ЭТАПЫ РАЗВИТИЯ ОСАДОЧНОГО БАССЕЙНА СЕВЕРО-ВОСТОКА ВОСТОЧНО-ЕВРОПЕЙСКОЙ ПЛАТФОРМЫ В ПРОТЕРОЗОЕ И ПАЛЕОЗОЕ НА ОСНОВЕ МНОГОЛЕТНИХ НАБЛЮДЕНИЙ ГЕОЛОГИЧЕСКИХ РАЗРЕЗОВ И ИССЛЕДОВАНИЙ ГЛУБОКИХ СКВАЖИН
}

\author{
Сулима Александр Иванович1, \\ super.sulima2013@yandex.ru
}

\author{
Плюснин Алексей Владимирович², \\ plysnin_av@irkutskoil.ru
}

Плешков Лев Дмитриевич', levpleshkov@gmail.com

\section{Трубин Ярослав Сергеевич 3 , iyr-2009@mail.ru}

Тимофеев Владислав Дмитриевич1, immrill@yandex.ru

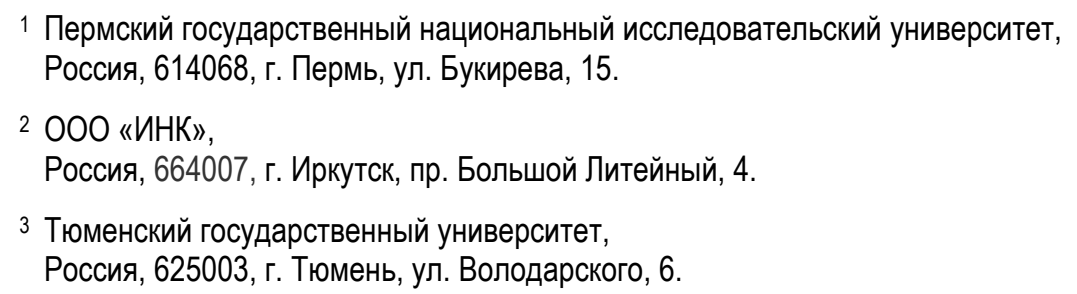

Актуальность исследования обусловлена необходимостью переосмысления строения осадочного чехла северо-востока Восточно-Европейской платформы с позиций секвенс-стратиграфического анализа, что даст возможность построения эвстатической кривой и станет основой более детального изучения.

Цель: расчленение отложений на секвенсы первого и второго порядка и построение кривой колебания уровня моря.

Объекты: геологические разрезы западного склона Урала, северо-востока Восточно-Европейской платформы и глубокие скважины Ниримской, Кулигинской, Соколовской, Сивинской, Северокамской, Сухобизярской, Юмышской, Веслянской и Осиниевской площади.

Методы: полевые работы, межскважинная корреляция, литолого-фациальный, эвстатический и бассейновый анализ.

Результаты. Проведённое комплексное обобщение данных глубокого бурения и полевых наблюдений геологических разрезов позволило с позиций секвенс-стратиграфического анализа выделить и описать пять секвенсов первого порядка (мегасеквенсы), сменяющих друг друга снизу вверх: рифейский; вендский; нижнедевонско-турнейский; визейско-нижнепермский; нижнепермскийверхнепермский. Мегасеквенсы, в свою очередь, были разделены на секвенсы второго порядка (суперсеквенсы): нижнедевонский; нижнедевонско-нижнефранский; среднефранско-турнейский; визейско-башкирский; московско-ассельский; сакмарско-кунгурский; усримско-верхнепермский. К границам секвенсов приурочены стратиграфические перерывы разной продолжительности. Самыми длительными являются перерывы между нижним рифреем и верхним вендом, а также верхним вендом и нижним девоном. Секвенсстратиграфрический анализ позволил впервые построить эвстатическую кривую для данного района. Максимальные регрессии пришлись на эмский, визейский и московский века и на средне-позднепермскую эпохи. К ним приурочен тракт низкого стояния уровня моря и основные терригенные коллекторы. Максимальные трансгрессии отмечены в фраменский, турнейский, башкирский ассельский века. К ним приурочены органогенные постройки, формировавшиеся на тракте высокого стояния уровня моря. Таким образом, прослежена геологическая история осадконакопления северо-востока Восточно-Европейской платформы.

\section{Ключевые слова:}

Секвенс-стратиграфия, верхний палеозой, Восточно-Европейская платформа, Волго-Уральская нефтегазоносная провинция, Пермский край, корреляция скважин, литолого-фациальный анализ, эвстатический анализ, бассейновый анализ.

\section{Введение}

За более чем двухсотлетнюю историю изучения Восточно-Европейской платформы (ВЕП) исследователями накоплен обширный фактический материал по строению, истории геологического развития и стратификации отложений. Наиболее изучена восточная часть платформы, к которой приурочена ВолгоУральская антеклиза, отвечающая одноименной нефтегазоносной провинции (рис. 1, $a$ ). Здесь высокая плотность структурного и поискового бурения. Территория Пермского края по-своему является уникальной. Именно здесь под руководством П.И. Преображенского в 1929 г. была добыта первая нефть и открыта Волго-Уральская нефтегазоносная провинция (ВУНГП). Территория края является стратотипической местностью и геологическим полигоном с типовыми разрезами девонской, каменноугольной и пермской систем. 


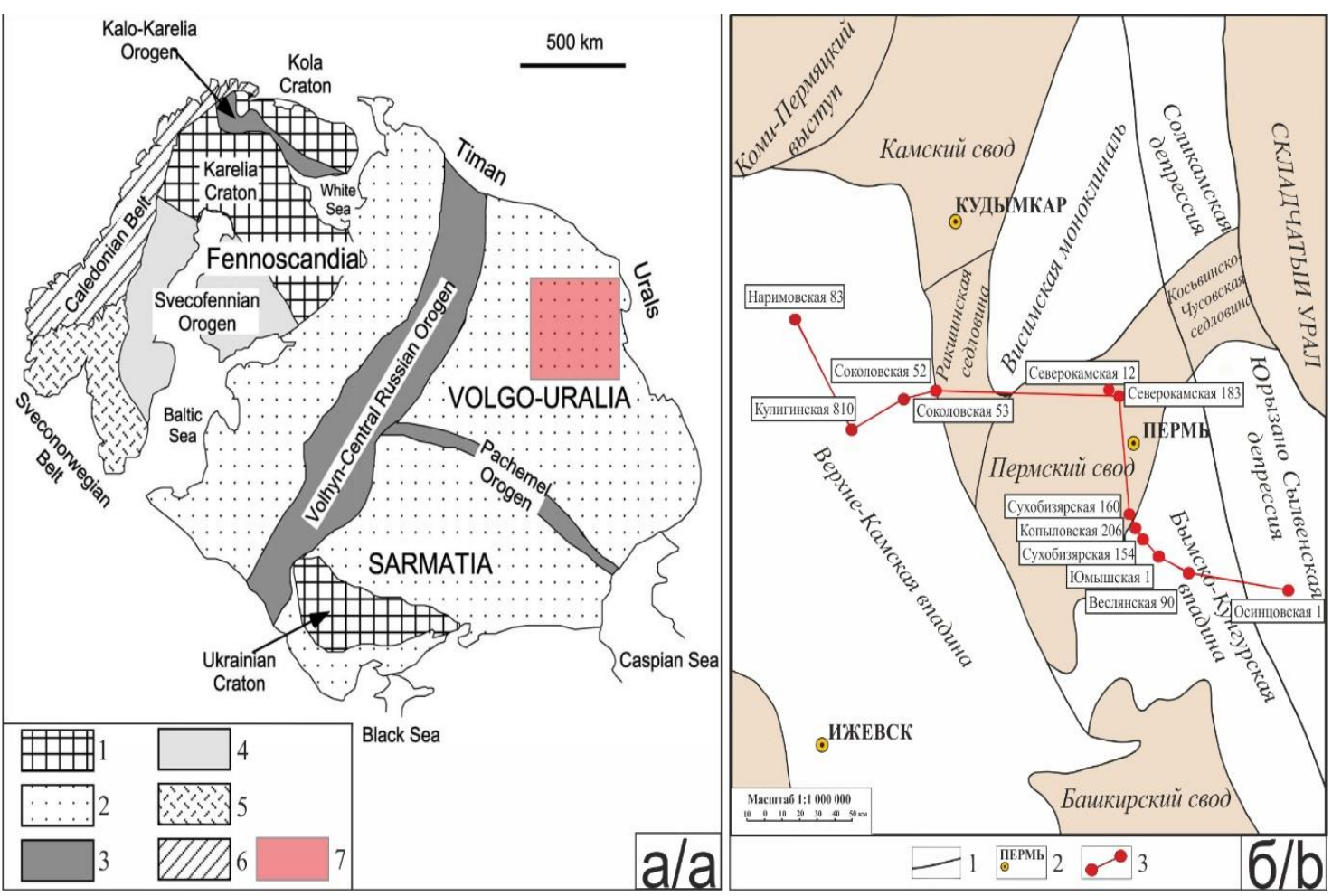

Рис. 1. Геологическая карта, показывающая основные тектонические единицы Восточно-Европейской платформы [1] (а): 1 - архейский фундамент; 2 - кратонный фундамент покрыт фанерозойскими породами; 3 - возраст 1,9-1,8 млрд лет коллизионного орогена; 4 - возраст 1,9-1,8 млрд лет, аккреционный ороген; 5 - мезопротерозойский ороген; 6 - палеозойский ороген; 7 - район исследования. Тектоническая схема изучаемого района (б): 1 - границы тектонических структур; 2 - населенные пункты; 3 -скважины и линия построения профиля

Fig. 1. Geological map showing the main tectonic units of the East European platform [1] (a): 1 - exposed Archean basement; 2 - cratonic basement covered by phanerozoic rocks; 3 -1,9-1,8 Ga collisional orogen; 4-1,9-1,8 Ga accretional orogen; 5 - mesoproterozoic orogen; 6 - paleozoic orogen; 7 - study area. Tectonic diagram of the study (b): 1 -boundaries of tectonic structures; 2 -cities; 3 -wells and the profile line

В последние годы для повышения надежности стратиграфических построений и успешного проведения геологоразведочных работ становится актуальным привлечение секвенс-стратиграфического анализа. Это обстоятельство и высокий ресурсный потенциал ВУНГП диктуют потребность в проведении данных работ по секвенс-стратиграфическому анализу, направленных на выявление закономерностей формирования отложений осадочного чехла в изучаемом районе.

В предлагаемой работе авторами предпринята попытка секвенс-стратиграфического анализа осадочного чехла по линии составленного ими профиля (рис. 1, б) с выделением секвенсов 1-го и 2-го порядков, на основании которого удалось построить эвстатическую кривую колебания уровня моря для протерозойской акротемы и палеозойской эратемы. Таким образом, прослежена история геологического развития исследуемой территории. Показаны трансгрессивнорегрессивные тренды и тектонические события, оказавшие влияние на эвстатику северо-восточной части ВЕП. Приведена краткая характеристика геологических объектов, в которых можно наблюдать разрезы изучаемого стратиграфического интервала. Эта характеристика является наглядным путеводителем по описываемым осадочным последовательностям.

\section{Материал и методы исследования}

Основой работы является материал, накопленный и обобщенный во время полевых наблюдений геологических объектов в районе западного склона Урала, Предуральского краевого прогиба, равнинной части Пермского края, с включением результатов ранее опубликованных авторских работ на эту тему.

Краткое описание геологических разрезов. Авторы приводят краткий список наиболее представительных типовых разрезов северо-востока ВЕП в пределах Пермского края. Общий метраж изученных разрезов составил порядка 835 м. Далее авторы дают краткую привязку и описание некоторых наиболее представительных геологических разрезов, наглядно иллюстрирующих описываемые ниже осадочные последовательности (рис. 2, a).

Разрез «Ослянка» лежит к востоку от города Кизела Пермского края, на запад от главного водораздельного хребта Урала и представляет собой вытянутый с севера на юг горный хребет длиной 16 км. Высота главной вершины 1119,4 м. Южным продолжением хребта Ослянка являются заповедные Басеги. Объект интересен тем, что он даёт возможность ознакомиться с терригенным разрезом верхнего рифея, выделенным в одноименную ослянскую свиту. 

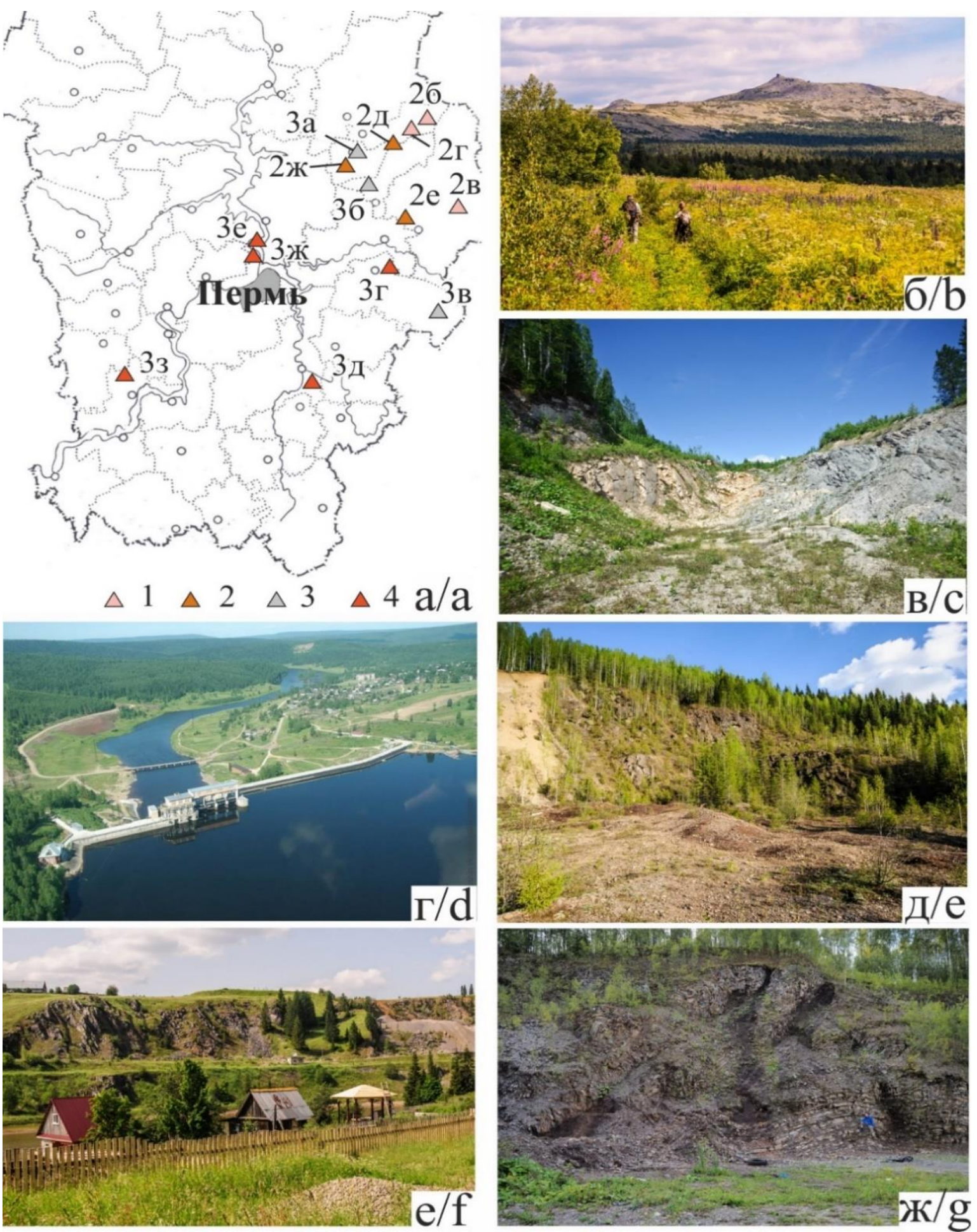

Рис. 2. Схема расположения описываемых геологических разрезов на геологической карте Пермского края и их номера (a): 1) протерозойские отложения; 2) девонская система; 3) каменноугольная система; 4) пермская система. Геологические разрезы протерозойских и девонских отложений (б-ж): б) гора Ослянка, стратотип ослянской свиты рифея; в) карьер «Борок», вскрывший мраморы клыктанской свиты рифея со строматолитами; г) разрез «Широковский», как местонахождение эдикарской фауны; д) разрез «Хорошевка», девонский риф; е) разрез «Пашийский гребешок» с карбонатными отложениями верхнего девона; ж) разрез «Коксохим», местонахождение девонских климениид

Fig. 2. Layout of the described geological sections on the map of the Perm Territory and their numbers (a): 1) Proterozoic deposits; 2) Devonian system; 3) Carboniferous; 4) Permian system. Geological sections of Proterozoic and Devonian sediments $(b-g)$ : b) mount Oslyanka, stratotype of the "Oslyanskaya» suite of the Riphean; $c$ ) "Borok» quarry, which exposed the marbles of the Riphean Klyktan Formation with stromatolites; d) section "Shirokovsky», as the location of the Edikar fauna; e) section "Khoroshevka», Devonian reef; f) section "Pashiiskiy grebeshok» with Upper Devonian carbonate deposits; g) section «Koksokhim», location of the Devonian Climenides 
Свита имеет выдержанный литологический состав и нацело сложена светло-серыми с желтым оттенком и серыми мелкозернистыми кварцитопесчаниками, состоящими из регенерированных зерен кварца, иногда в небольшом количестве присутствуют полевые шпаты. На поверхностях напластования местами отмечаются знаки волновой ряби (рис. 2, б).

Разрез «Борок» расположен в 2 км восточнее пос. Старый Бисер в долине реки Койвы. Разрез интересен тем, что в нем обнажены мраморы и мраморизованные известняки клыктанской свиты верхнего рифея. Цвет мраморов и мраморизованных известняков бледно-серый, розоватый, вишневый, фиолетовый. Среди мраморов встречаются строматолиты (рис. 2, в).

Разрез «Широковский» расположен на левом берегу Широковского водохранилища вблизи устья реки Няр, на территории городских округов Кизела и Губахи. В обрыве цокольной террасы и по берегам водохранилища обнажаются плотные серо-зеленые и палевые аргиллиты и алевролиты чернокаменской свиты верхнего венда. Эти породы перекрываются отложениями среднего девона. Этот разрез - единственное в крае место, где достоверно были обнаружены образцы, содержащие бесскелетную эдиакарскую фауну (рис. 2, г).

Долина реки Косьвы в районе города Губаха изобилует уникальными геологическими объектами, в которых обнажен весь разрез карбона, частично девона и нижней перми.

Разрез «Хорошевка» находится в карьере на правом берегу реки Хорошевки, притока Косьвы, в 1 км от её устья, на территории городского округа «Губаха». Здесь можно увидеть прекрасные разрезы среднего и верхнего отделов девонской системы. Темноцветные аргиллиты франского яруса представляют собой относительно глубоководный карбонатный разрез. Здесь встречаются отдельные фрагменты панцирей древних рыб (плакодерм) вместе с раковинами брахиопод и другой бентосной фауной. Богаты органическими остатками и глинистые известняки эйфельского яруса, содержащие большое количество массивных колоний табулятных и одиночных четырёхлучевых кораллов (рис. 2, 2 ).

Разрез «Пашийский Гребешок» находится на правом берегу Пашийского пруда, на северной окраине пгт Пашия Горнозаводского городского округа. Разрез приурочен к Безгодовско-Пашийской синклинальной зоне, к скальным выходам смятых в складки известняков фаменского яруса. Отложения представлены серыми и светло-серыми массивными биогермными известняками, реже коричневато-серыми слоистыми доломитами. Мощность прослоев известняков возрастает от 1,5-2 (в нижней части разреза) до $15 \mathrm{M}$ (в верхней), а доломитов соответственно уменьшается от 30 до 0,5 м (рис. $3, e$ ).

Разрез «Ядро» находится на левом берегу Косьвы, напротив Губахинского коксохимического завода, и представлен автодорожной выемкой. Это территория городского округа «Губаха». Здесь вскрывается ядро Главной Кизеловской антиклинали, где можно увидеть доманиковый тип разреза фаменского яруса верхнего девона, представленный темно-серыми до черных глинистыми сланцами и аргиллитами фаменского яруса (рис. 2, ж).

Разрез «Губаха» находится на правом берегу p. Косьвы, вдоль железнодорожной линии, между старым и новым автомобильными мостами, несколько ниже посёлка Верхняя Губаха. Каменноугольные породы собраны здесь в мелкую дисгармоничную складчатость, осложнённую тектоническими разрывами. Это наиболее типичный разрез турнейского яруса. В известняках содержится фаунистический комплекс, состоящий главным образом из одиночных четырёхлучевых кораллов, также отмечены кустистые колонии табулятных кораллов - сирингопор, брахиоподы отряда продуктида и многочисленные крупные фораминиферы (рис. 3,a).

Разрез «Каменный город» представляет собой группу высоких останцев в южной части хребта Рудянский спой, которая завершается на севере протяжённым скальным гребнем и горой Крестовой. Разрез находится на территории Гремячинского городского округа. Скальные останцы высотой до 20 м составляют гряду, представленную песчаниками бобриковского горизонта нижнего отдела каменноугольной системы. Кварцевые средне- и мелкозернистые с примесью крупных зёрен песчаники слагают русло палеореки. Слоистость хорошо выраженная косая, прямолинейная и однонаправленная, образована сортировкой песчаного материала (рис. $3, \sigma$ ).

Разрез «Орёл» находится на территории Лысьвенского городского округа, к юго-западу от станции Кын, на окраине одноимённого посёлка. Разрез представляет собой скальные выходы известняков на правом берегу p. Большой Кын, самое крупное обнажение называется скала «Орёл». В этом разрезе представлены известняки, начиная с башкирского яруса среднего карбона, верхнего отдела каменноугольной системы, и заканчивая низами приуральского отдела пермской системы (ассельского и сакмарского возраста) (рис. 3, в).

Разрез «Травянка» находится на восточной окраине города Лысьва, в старом карьере, на террасе реки Большая Травянка. Нижнепермские отложения представлены конгломератами урминской свиты артинского яруса с подчинёнными прослоями песчаников и слагают «пермскую» молассовую формацию. Среди галек встречены отпечатки нижнепермских растений, в частности папоротников, и включения фауны в виде фрагментов одиночных кораллов и раковин брахиопод (рис. 3, г).

Разрез «Ермак» на одноимённой скале можно увидеть на правом берегу реки Сылвы в Кунгурском районе. В обрыве высокой террасы вскрывается рифовая постройка артинского яруса. В рифовых известняках, отличающихся массивностью и кавернозностью, встречаются многочисленные зеленые водоросли (основные рифостроители), сетчатые колонии разнообразных мшанок-криптостомат, раковины брахиопод (продуктиды, строфомениды, теребратулиды и ринхонеллиды), двустворчатых и брюхоногих моллюсков. Межрифовые отложения представлены плитчатыми известняками, доломитами и мергелями (рис. $3, \partial$ ). 

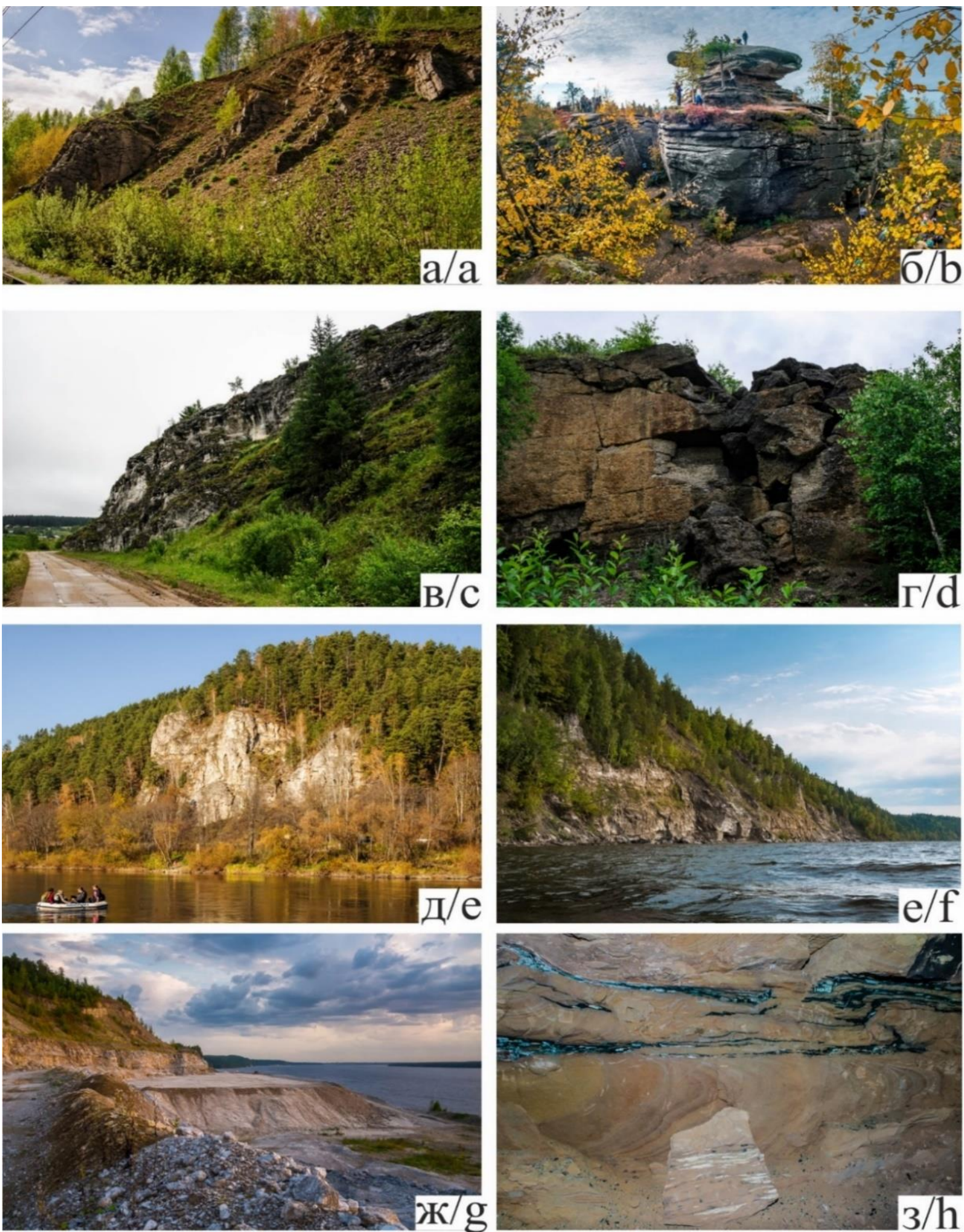

Рис. 3. Геологические разрезы каменноугольных и пермских отложений: а) разрез «Губаха», типичный для турнейского яруса; б) разрез «Каменный город», песчаниковые останщы визейского яруса; в) разрез «Кын», пограничные отложения каменноугольной и пермской систем; г) разрез "Травянка», артинская моласса; д) разрез «Ермак», палеориф кунгурского возраста; е) разрез «Залесная», с сульфатными породами кунгурского яруса; ж) разрез Чумкаский карьер; з) разрез "Самосадки», пермские терригенные отложения

Fig. 3. Geological sections of Carboniferous and Permian deposits: a) Gubakha section, typical of the Tournaisian stage; b) section «Kamenny gorod», sandstone outliers of the Visean stage; c) Section «Kyn», boundary deposits of the Carboniferous and Permian systems; d) section "Travyanka», molasses from Artian stage; e) section "Ermak», paleobiegerm of Kungurian age; f) section «Zalesnaya», with sulfate rocks of the Kungurian stage; g) "Chumkasky» quarry; h) section «Samosadki», Permian terrigenous deposits 
Разрез «Залесная» расположен на левом берегу Камского водохранилища, непосредственно у деревни Залесная Добрянского городского округа, чуть севернее города Перми. Разрез представляет собой череду обнажений пород в береговых обрывах и недействующий гипсовый карьер. Здесь обнажена граница карбонатно-сульфатной толщи кунгурского яруса и сульфатно-карбонатная толща соликамской свиты уфимского яруса (рис. 3, e, ж).

Разрез «Самосадки» представлен в горных выработках Самосадкинского месторождения волконскоита и находится в урочище Самосадки, что в 5 км к северу от села Шлыки Частинского муниципального округа, на склоне горы Каравашек. Несколькими штольнями вскрыты красноцветные терригенные отложения казанского яруса, представленные русловыми фациями. К базальным частям палеорусел, особенно к их излучинам, приурочены конгломераты, в залегающих выше желтовато-бурых косослоистых песчаниках встречены скопления окаменевшей древесины, частично замещенной волконскоитом (рис. 3,3 ).

Региональные построения. С целью построения регионального геологического профиля были выбраны 10 скважин, вскрывших фундамент или почти достигших его поверхности, с полным комплексом геолого-геофизической информации: гамма-каротаж, нейтронный каротаж, описание керна и шлама. Названия площадей и номера скважин, перечисленные в направлении с запада на восток, следующие: Ниримская скв. 83, Кулигинская скв. 810, Соколовская скв. 52, Сивинская скв. 3, Северокамская скв. 183, Сухобизярская скв. 160, Юмышская скв. 1, Веслянская скв. 90, Осинцевская скв. 1. Следует отметить, что для исследований также были использованы данные по разрезу Северокамской скв. 12, пробуренной в районе скв. 183. Данная скважина вскрыла кристаллический фундамент, но не была охарактеризована радиоактивным каротажом. Общая величина проходки выбранных скважин составила 23821 м, суммарный метраж проходки с отбором керна 7151 м, отобрано и описано керна в объеме 7580 м. Интерпретация кривых ГИС и идентификация пород контролировались описанием шлама из дел скважин в проблемных интервалах разреза. Выравнивание корреляционного профиля произведено по кровле девонских терригенных отложений (кровля терригенной пачки тиманского горизонта нижнефранского подъяруса), сопряженной с сейсмогеологическим отражающим горизонтом (ОГ) III.

Для построения корректных границ стратиграфических секвенсов между скважинами использовались сейсмогеологические данные из опубликованных источников [2-4], структурных карт (карт стратоизогипс) маркирующих горизонтов протерозойской акротемы и палеозойской эратемы и временных разрезов, находящихся на линии профиля.

Стратификация разрезов скважин производилась по принятым стратиграфическим схемам для протерозойской акротемы, девонской, каменноугольной и пермской систем. Так, для верхнего протерозоя применена «Стратиграфическая схема рифейско- вендских отложений Волго-Уральской области» [5]. Нижнерифейские отложения на западе профиля приурочены к кырпинской серии, вендские по всему профилю - к кудымкарской и бородулинской серии верхнего венда.

Подразделения девонской системы отображены в соответствии с «Унифицированной субрегиональной стратиграфической схемой верхнедевонских отложений Волго-Уральского субрегиона» [6]. В отличие от прежней стратиграфической схемы по девонской системе 1990 г., тиманский горизонт полностью отнесен к нижнефранскому подъярусу, а подстилающий его пашийский горизонт вошел в состав живетского яруса среднего девона. В верхнефранском подъярусе мендымский горизонт, подстилающий нерасчлененные верхнефранские отложения (воронежский, евлановский, ливенский горизонты), отнесен к речицкому горизонту.

Отложения каменноугольной системы по профилю сопряжены с действующей в данное время «Стратиграфической схемой каменноугольных отложений» [7].

Стратиграфия пермской системы претерпела значительные изменения по сравнению с прежней схемой 1990 г. Согласно Постановлению Бюро МСК от 08.04.2005 г. о модернизации верхнего отдела пермской системы Восточно-Европейской стратиграфической шкалы, верхний отдел был подразделен на средний (биармийский) и верхний (татарский) отделы. Уфимский ярус был присоединен к нижнему (приуральскому) отделу. Эта обновленная стратиграфическая схема Волго-Уральской области [8] была использована при построении профиля.

Для детального исследования разреза авторами применен секвенс-стратиграфический анализ, нацеленный на выявление и интерпретацию следов колебания уровня моря среди осадочных пород, а также детальные исследования строения, функционирования и эволюции осадочного палеобассейна.

В рамках работы авторами были выделены секвенсы, которые понимаются как относительно согласная последовательность генетически взаимосвязанных пластов, ограниченная в кровле и подошве стратиграфическими несогласиями или соответствующими им согласными границами. Секвенс сложен последовательностью системных трактов и интерпретируется как геологическое тело, сформированное в период между максимумами падения относительного уровня моря [9]. Системный тракт - это латеральный ряд синхронных седиментационных систем или фаций. Формирование системного тракта связано с определенным положением уровня моря. Это отражено в названиях системных трактов: окраинношельфовый тракт (ОШТ), тракт низкого стояния (ТНC), трансгрессивный системный тракт (ТCT), тракт высокого стояния (ТВC). Системные тракты характеризовались по преобладающему типу отложений и представлены аллювиальными, флювиальными, приливно-отливными, дельтовыми фациями, фациями внутреннего (супралиторали, литорали, верхней сублиторали) и внешнего (сублиторали нижней, псевдоабиссали) шельфа [10]. 
Для фанерозойской эонотемы выделяют циклы эвстатических колебаний пяти порядков продолжительностью от сотен миллионов до десятков тысяч лет. Иерархия секвенсов включает 5 порядков: 1 порядок - более $50 \mathrm{MA;} 2$ порядок - 3-50 МА; 3 порядок 0,5-3 МА; 4 порядок - 0,08-0,5 МА; 5 порядок 0,03-0,08 МА [11]. Авторы в своей работе выделяют секвенсы первого и второго порядка. Выделение секвенсов 2-го порядка облегчается тем, что они отделяются региональными несогласиями. Для них авторами охарактеризованы системные тракты, характеризующие этапы развития осадочного бассейна. $\mathrm{Ce}$ квенсы второго порядка подразделяются на более мелкие и имеют сложное строение, заслуживающее отдельного рассмотрения.

\section{Краткие сведения о геологическом строении района исследования}

В географическом и административном отношении региональный субширотный профиль приурочен к восточной окраине Восточно-Европейской равнины, начинаясь в южной части Верхнекамской возвышенности на западе и заканчиваясь на востоке в районе Уфимского плато. Он протягивается преимущественно в направлении с северо-запада на юго-восток. Первые две скважины (Ниримская 83 и Кулигинская $810)$ находятся на северо-востоке Кировской области и Республики Удмуртия соответственно, а остальные скважины пробурены в западной, центральной и юговосточной частях Пермского края. Протяженность профиля составляет 312,8 км.

В тектоническом плане профиль характеризует строение восточной окраины Восточно-Европейской (Русской) платформы, прилегающей к Складчатому Уралу, в северо-восточной части Волго-Уральской антеклизы (рис. 1,a). Линия профиля пересекает с запада на восток Верхнекамскую впадину, Ракшинскую седловину, Пермский свод, Бымско-Кунгурскую моноклиналь, Юрюзано-Сылвенскую депрессию. По верхнедевонско-турнейским отложениям профиль в своей восточной части проходит через Калининскую впадину Камско-Кинельской системы прогибов (ККСП). Конечная восточная Осинцевская скважина 1 пробурена в переходной от платформы к Уралу зоне Предуральского краевого прогиба, выделяемого по нижнепермской молассе.

Геологическое строение восточной периферии Русской платформы на площади Среднего Предуралья определяется наличием двух крупных структурных комплексов, залегающих с резким угловым несогласием: нижним - архейсконижнепротерозойским, представляющим собой складчатый фундамент, и верхним - фанерозойским осадочным чехлом, который подразделен на рифейский, вендский и верхнепалеозойский структурные этажи [12, 13].

Складчатый фундамент вскрыт пятью скважинами: $810,52,3,12,1$ на глубину 50-300 м. Высотные отметки поверхности фундамента неравномерны и вдоль линии профиля варьируют от -2400 до -4500 м. Фундамент разновозрастный, гетерогенный, сложен гранито-гнейсами, на востоке - гранито-гнейсами и амфиболитами. Воздымание фундамента в центральной части профиля сопряжено с Пермским сводом. В западной части профиля наблюдается морфологически выраженная интенсивная раздробленность фундамента на приподнятые и опущенные блоки.

Строение рифейского структурного этажа резко отличается от морфологии фундамента. Рифейские отложения залегают здесь с резким угловым несогласием на гранито-гнейсовых породах кристаллического фундамента, вследствие континентальной денудации [3]. Поэтому на приподнятых блоках фундамента, особенно в западной части профиля, отложения рифея отсутствуют или представлены в виде эрозионных останцев. На исследуемом профиле отложения нижнего рифея $\left(\mathrm{RF}_{1}\right)$ вскрыты скважинами 52 и 12. Они представлены его низами терригенного состава: красноцветными неотсортированными песчаниками, гравелитами, алевролитами с прослоями доломитов мощностью 19-200 м (рис. 4).

Отложения вендского терригенного комплекса по всему исследуемому профилю развиты повсеместно, они со стратиграфическим и угловым несогласием залегают на разновозрастных породах нижнего рифея или покрывают денудированную поверхность фундамента на его выступах (рис. 4). Литологически они представлены песчано-глинистыми породами верхнего венда $\left(\mathrm{V}_{2}\right)$, отложения нижнего венда на площади размыты [14]. Подошва вендского комплекса наиболее приподнята на юго-западном приграничном окончании площади, где абсолютные отметки составляют -2300-2400 м, и наиболее погружена на восточном окончании профиля в районе скв. 1 (отметка 3020 м). Наибольшая стратиграфическая полнота разрезов верхнего венда и мощность характерны для центральной части профиля (скв. 12), где мощность достигает 947 м. В западной и восточной частях исследуемого профиля мощности разреза составляют 407-450 м.

Нижнедевонско-нижнефранский терригенный комплекс, сложенный преимущественно терригенными породами эмского $\left(\mathrm{D}_{1} \mathrm{e}\right)$, эйфельского $\left(\mathrm{D}_{2} \mathrm{ef}\right)$, живетского $\left(\mathrm{D}_{2} \mathrm{~g}\right)$ ярусов и тиманского горизонта франского яруса $\left(\mathrm{D}_{3} \mathrm{f}_{1}\right)$, с резким угловым и стратиграфическим несогласием лежит в основании верхнепалеозойской толщи Среднего Приуралья. Терригенные отложения представлены в основном песчаниками, алевролитами и аргиллитами, в средней части разреза (эйфельский ярус) выделяется карбонатная пачка.

Поверхность терригенного девона в западном начале профиля залегает на высотных отметках от 2100 до -1800 м. В середине профиля, на Северокамской вершине Пермского свода, поверхность приподнята до -1700 м, а на восточном окончании профиля погружена до -2570 м. Мощность терригенного девона на западе составляет 80-120 м, на Пермском своде - 180-200 м, на востоке профиля девонские терригенные отложения выклиниваются.

Верхнедевонско-турнейский карбонатный комплекс охватывает возрастной интервал от саргаевского горизонта среднефранского подъяруса верхнего 
девона до кизеловского горизонта верхнетурнейского подъяруса нижнего карбона включительно. Он сложен различными карбонатами франского $\left(\mathrm{D}_{3} \mathrm{f}_{2-3}\right)$, фаменского $\left(\mathrm{D}_{3} \mathrm{fm}\right)$ и турнейского $\left(\mathrm{C}_{1} \mathrm{t}\right)$ ярусов.

Геологическое строение верхнедевонскотурнейского карбонатного комплекса выражается в системе зон мелководного шельфа и цепочек сопряженных отрицательных впадин с выровненными днищами и крутыми бортами, осложненными рифо- генными образованиями [3, 14]. Начиная с саргаевского времени выделяются зоны мелководного шельфа и относительно глубоководных шельфовых впадин. Глубинные отметки залегания поверхности верхнедевонско-турнейских отложений вдоль профиля составляют на западе от -1400 м, поверхность воздымается на Пермском своде до -1230 м, а на восточном окончании профиля (скв. 1) погружается до 2030 м, то есть перепад отметок достигает 800 м.

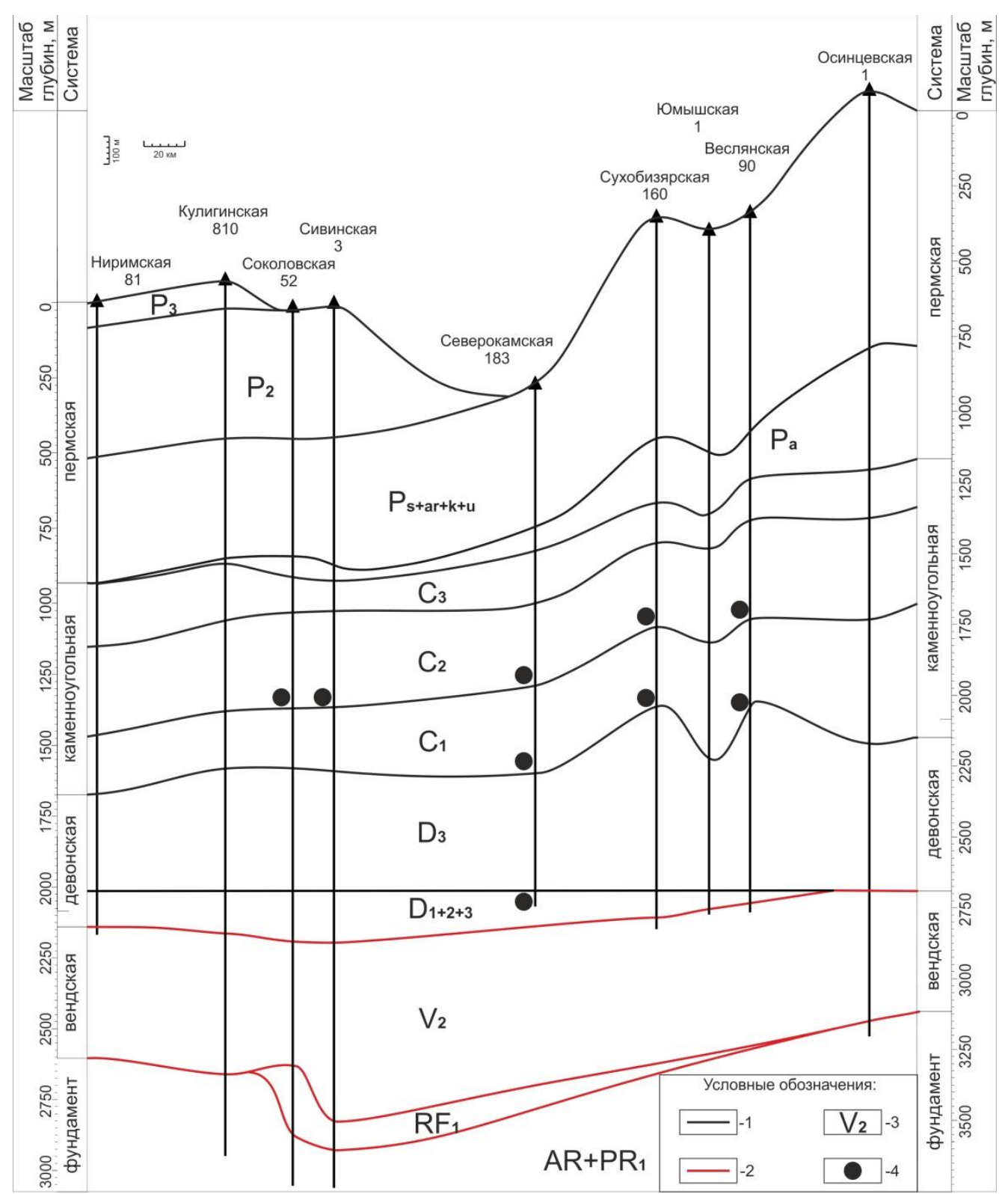

Рис. 4. Схематический региональный субширотный палеогеологический профиль по линии скважсин северо-востока Восточно-Европейской платформы:: 1 - стратиграфические граниџь;; 2 - секвенс-стратиграфические границы;; 3 - стратиграфический индекс; 4 - продуктивные пласты

Fig. 4. Schematic sublatitudinal paleogeological profile for the studied wells in the northeast of the East European regional platform: 1 -stratigraphic boundaries; 2 -sequence stratigraphic boundaries; 3 -line index; 4 -productive formations

Комплекс характеризуется зональным строением, где фациальные зоны в виде обширных полос северовосточного простирания пространственно сменяются в направлении на восток и юго-восток по всей протяженности профиля [4].
Исследуемый профиль пересекает следующие фациальные зоны:

1. Зона супралиторали/литорали (доломиты, известняки карбонатные брекчии).

2. Зона приливно-отливных равнин (доломиты). 
3. Мелководный шельф (шельфовая лагуна и внешний открытый шельф).

4. Зона водорослевых построек бортовых гряд и мозаичных карбонатных платформ. Зона подразделяется на северо-западную и юго-восточную водорослевые гряды позднефранско-среднефаменского возраста, состоящие из отдельных биогермов высотой 420-470 м, которые сложены различными органогенно-обломочными известняками и облекаются сверху слоистыми карбонатами позднефаменско-турнейского возраста мощностью 70-130 м. Ширина биогермной зоны 4-6 км, расстояние между северо-западным и юго-восточным бортами составляет $35-45$ км.

5. Зона заполнения прогибов Камско-Кинельской системы клиноформной турнейской толщей (глинистые и карбонатные клиноформы). Склоновые турнейские клиноформы представлены преимущественно карбонатными телами, приосевые и осевая части сложены глинистыми клиноформенными телами мощностью 112-120 м, последовательно перекрывающими друг друга в центральных частях впадины [14]. Общая мощность 280-350 м. Ширина зоны заполнения на исследуемом профиле составляет 37 км, ширина осевой части - 11 км, мощность всего комплекса -470 м.

6. Фачиальная зона доманикового мелководья с развитием водорослевых биостромовых банок. К востоку от юго-восточной бортовой зоны выделяется собственно зона зарифового мелководья, сложенная известняково-доломитовой формацией [15]. Ширина ее на исследуемом профиле составляет около 80 км. Мощность разреза комплекса, вскрытого восточной Осинцевской скв. 1, составляет $520 \mathrm{M}$.

Визейский терригенный комплекс. Визейская терригенная толща представлена нижневизейским подъярусом $\left(\mathrm{C}_{1} \mathrm{v}_{1}\right)$ в составе радаевского, бобриковского и нижней части тульского горизонтов. Визейские терригенные отложения прослежены по всему профилю и представлены переслаиванием аргиллитов, алевролитов, песчаников, иногда с прослоями конгломератов и карбонатных разностей [16]. Мощность толщи составляет 12-36 м на западе, достигая максимума 113 м на территории прогиба ККСП (Юмышская скв. 1).

Верхневизейско-башкирский карбонатный комплекс сложен известняково-доломитовой толщей в составе верхневизейского подъяруса $\left(\mathrm{C}_{1} \mathrm{~V}_{2}\right)$, серпуховского яруса $\left(\mathrm{C}_{1} \mathrm{~s}\right)$ и башкирского яруса среднего карбона $\left(\mathrm{C}_{2} \mathrm{~b}\right)$ c возрастающей сульфатизацией вверх по разрезу. Верхняя башкирская часть представлена преимущественно слоистыми известняками с брекчией в кровле. Мощность толщи -220-314 м.

Средне-верхнекаменногольный

(московскогжельский) карбонатный комплекс. Стратиграфически представлен московским ярусом среднего карбона $\left(\mathrm{C}_{2} \mathrm{~m}\right)$ и нерасчлененными касимовским и гжельским ярусами верхнего карбона $\left(\mathrm{C}_{3} \mathrm{k}-\mathrm{g}\right) \mathrm{B}$ основании комплекса залегают терригенно-карбонатные мелководные отложения верейского горизонта мощностью 56-72 м, сложенные в западной части профиля мерге- лями, аргиллитами и известняками (до скв. 183), в средней и восточной частях - известняками и аргиллитами, в краевой восточной части - переслаиванием известняков, аргиллитов и алевролитов.

Выше залегает каширско-гжельская карбонатная толща среднего и верхнего карбона, сложенная переслаиванием доломитов, известняков с подчиненными прослоями аргиллитов. Верхняя часть толщи значительно сульфатизирована. Мощность изменяется от 400 до 540 м. Мощность всего комплекса составляет 460-610 м.

Нижнепермские отложения в составе ассельского $\left(\mathrm{P}_{1} \mathrm{a}\right)$, сакмарского $\left(\mathrm{P}_{1} \mathrm{~s}\right)$, артинского $\left(\mathrm{P}_{1} \mathrm{ar}\right)$, кунгурского $\left(\mathrm{P}_{1} \mathrm{k}\right)$, уфимского $\left(\mathrm{P}_{1} \mathrm{u}\right)$ ярусов на линии исследуемого профиля представлены повсеместно и поярусно характеризуются сильной литофациальной изменчивостью и пятью-семью зонально вытянутыми субмеридиональными полосами, сменяющими друг друга в субширотном направлении. Верхняя часть комплекса (уфимский ярус) выполнена отложениями фаций переходными к континентальным.

На западе профиля преобладают сульфатные и карбонатно-сульфатные отложения, в центральной части - карбонатные (доломитово-известняковые) породы, на востоке - глинисто-карбонатные, сульфатно-карбонатно-терригенные и обломочные осадки. Обломочная серия пород в краевой восточной Осинцевской скв. 1 представлена артинской молассой (гравелиты, алевропесчаники, аргиллиты) мощностью 153 м.

Мощность нижнепермских отложений увеличивается с запада от 440 (Ниримская скв. 81) до 1290 м (Осинцевская скв. 1).

Среднепермские отложения в объеме казанского $\left(\mathrm{P}_{2} \mathrm{kz}\right)$ и уржумского $\left(\mathrm{P}_{2} \mathrm{ur}\right)$ ярусов последовательно перекрывают друг друга в направлении с востока на запад, начинаясь с Пермского свода западнее скв. 183. Они сложены красноцветными глинистыми и мергелистыми породами с прослоями песчаников и алевролитов мощностью 20 м на востоке, до 470 м на западе (скв. 52).

Верхнепермские отложения представлены в объеме нерасчлененных северодвинского и вятского ярусов $\left(\mathrm{P}_{3} \mathrm{~s}-\mathrm{v}\right)$ только на западном начале профиля песчано-глинистыми породами мощностью до 100 м (песчаники, аргиллиты) с прослоями озерных афанитовых известняков.

Нефтегазоносность осадочного чехла. Из имеющихся нефтегазоносных комплексов на территории профиля промышленная нефтеносность подтверждена скважинами на Сергеевском месторождении (Соколовская скв. 52 - башкирский пласт Бш), на Сивинском месторождении (Сивинская скв. 3 - верейский пласт $\mathrm{B}_{3} \mathrm{~B}_{4}$; башкирский пласт Бш), на Северокамском месторождении (Северокамская скв. 183 - верейский пласт $\mathrm{B}_{3} \mathrm{~B}_{4}$; башкирский пласт Бш; визейский пласт Тл $;$; пласт До терригенного девона), на Баклановском месторождении (Сухобизярская скв. 160 верейский пласт $\mathrm{B}_{3} \mathrm{~B}_{4}$; башкирский пласт Бш; визейский пласт Тл 2 ), на Ергачинском месторождении (Веслянская скв. 90 - башкирский пласт Бш; визейские пласты Тлг, Бб, Мл) (рис. 4). 


\section{Результаты исследования}

Современное исследование осадочных бассейнов основано на секвенс-стратиграфическом анализе [17-21]. В результате анализа строения осадочного чехла на северо-востоке ВЕП выделены следующие секвенсы первого порядка (мегасеквенсы, обозначаются SQ) и соответствующие секвенсы второго порядка (суперсеквенсы, обозначаются $\mathbf{S q}$ ), сменяющие друг друга снизу вверх (таблица).

SQ1 соответствует рифейскому авлакогенному этапу. Подошва секвенса соответствует хорошо выраженной поверхности стратиграфического несогласия, которая отчетливо устанавливается по керну (контакт пород фундамента, представленных гнейсами и гранито-гейсами биотитовыми и пироксенамфиболовыми, с конгломерато-песчаниками серыми и зеленовато-серыми нижнего рифея) и по каротажным диаграммам (подошва секвенса SQ1 отбивается по резкому спаду значений ГК с 20 мкР/ч, характерных для гранито-гнейсов, до 5 мкР/ч для залегающей выше пачки базальных конгломератов в подошве нижнего рифея (рис. 5).

Рифейские отложения с угловым и стратиграфическим несогласием залегают на породах кристаллического архей-раннепротерозойского фундамента, включая кору выветривания. Они представлены грубообломочными аллювиальными и песчаными флювиальными отложениями, выше по разрезу перекрывающимися песчано-алевритовыми приливноотливными и карбонатными отложениями литорали.

Таблица. Выделенные мега- и суперсеквенсы Table. $\quad$ Distinguished mega and super sequences

\begin{tabular}{|c|c|c|c|}
\hline 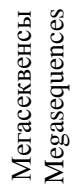 & $\begin{array}{c}\text { Возрастной интервал } \\
\text { Age interval }\end{array}$ & 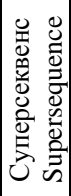 & $\begin{array}{c}\text { Возрастной } \\
\text { интервал } \\
\text { Age interval }\end{array}$ \\
\hline \multirow[t]{2}{*}{ SQ5 } & \multirow{2}{*}{$\begin{array}{c}\text { нижнепермский } \\
\text { (сакмарский)-верхнепермский } \\
\text { (татарский) } \\
\text { lower permian (sakmarian)- } \\
\text { upper permian (tatar) }\end{array}$} & $\mathrm{Sq} 7$ & $\begin{array}{c}\text { уфимско- } \\
\text { верхнепермский } \\
\text { ufimian-upper } \\
\text { permian }\end{array}$ \\
\hline & & Sq6 & $\begin{array}{c}\text { сакмарско- } \\
\text { кунгурский } \\
\text { sakmarian-kungurian }\end{array}$ \\
\hline \multirow{2}{*}{ SQ4 } & \multirow{2}{*}{$\begin{array}{c}\text { нижнекаменноугольный } \\
\text { (визейско)-нижнепермский } \\
\text { (accельский) } \\
\text { lower carboniferous (visean)- } \\
\text { lower permian (asselian) }\end{array}$} & $\mathrm{Sq} 5$ & $\begin{array}{c}\text { московско- } \\
\text { acсельский } \\
\text { moscowian-asselian }\end{array}$ \\
\hline & & $\mathrm{Sq} 4$ & $\begin{array}{c}\text { визейско- } \\
\text { башкирский } \\
\text { visean-bashkirian }\end{array}$ \\
\hline \multirow{3}{*}{ SQ3 } & \multirow{3}{*}{$\begin{array}{c}\text { нижнедевонско- } \\
\text { нижнекаменноугольный } \\
\text { (турнейский) } \\
\text { lower devonian-lower } \\
\text { carboniferous (tournaisian) }\end{array}$} & $\mathrm{Sq} 3$ & $\begin{array}{l}\text { среднефранско- } \\
\text { турнейский } \\
\text { middle frans- } \\
\text { tournaisian } \\
\end{array}$ \\
\hline & & $\mathrm{Sq} 2$ & $\begin{array}{l}\text { нижнедевонско- } \\
\text { нижнефранский } \\
\text { lower devonian- } \\
\text { lower frasnian }\end{array}$ \\
\hline & & $\mathrm{Sq} 1$ & $\begin{array}{c}\text { нижнедевонский } \\
\text { lower devonian }\end{array}$ \\
\hline \multicolumn{4}{|c|}{ крупный региональный перерыв/major regional break } \\
\hline SQ2 & венд/vendian & - & - \\
\hline SQ1 & рифей/riphean & - & - \\
\hline
\end{tabular}

В рифее вся платформа была представлена разрушающейся сушей и лишь отдельные ее участки по разломам опускались и существовали в виде больших грабенов-авлакогенов. Только в этих прогибах и накапливались продукты разрушения земной поверхности. В них рифей сложен в основном обломочными породами (песчаники, алевролиты, аргиллиты), обследовать которые можно в разрезе обнажения «Ослянка». Также они содержат прослои строматолитовых известняков, которые можно посмотреть в разрезе обнажения «Борок».

SQ2 отражает поздневендский этап формирования осадочного чехла, который распространен в районе всех скважин и стратиграфически выделяется снизу вверх в объеме кыквенской, верещагинской, кочевской и веслянской свит. Подошва секвенса соответствует хорошо выраженной поверхности стратиграфического несогласия на востоке профиля, которая отчетливо устанавливается по керну (контакт гранито-гнейсов биотитовых кристаллического фундамента с конгломерато-брекчией серой и темно-серой в подошве венда в Осинцевской скв. 1, а также по каротажным диаграммам этой скважины (резкий минимум ГК, НК и кажущегося сопротивления (КС) при возрастании потенциала самополяризации (ПС) для конгломератов, и повышенные значения ГК и НК при падении ПС для гранито-гнейсов, рис. 5).

На западе профиля подошве секвенса отвечает контакт вендских базальных конгломератов и песчаников серых и темно-серых с ниже залегающими известковистыми песчаниками SQ1, выделяемыми по керну и по комплексу ГИС (нижняя граница вендского секвенса SQ2 в Соколовской скв. 52 отбивается по понижению значений ГК и НК и возрастанию ПС, характеризующему пачку базальных конгломератов и песчаников).

Нерасчленённые отложения трактов низкого и высокого стояния представлены гравелитовопесчаниково-алевролитовыми флювиальными отложениями. ТВС формирует следующую последовательность, характерную для внутреннего шельфа: алевролитово-песчаные отложения литорали выше по разрезу переходят в песчаниково-алевролитово-глинистые отложения сублиторали и песчаниково-глинистые отложения сублиторали. Типичный осадочный чехол начинает формироваться в венде. Над древними авлакогенами начинают образовываться пологие обширные впадины - первые синеклизы. В них накапливаются песчаниково-глинистые породы: песчаники, алевролиты, аргиллиты. Породы зеленовато-серые и вишневокоричневые, имеют полимиктовый состав. Мощность венда небольшая - первые сотни метров. Венд залегает или на различных горизонтах рифея, или на породах фундамента. Таким образом, секвенсы SQ1 и SQ2 соответствуют первому этапу формирования осадочного чехла Восточно-Европейской платформы, выделяемому в доплитный этап. Породы венда можно обнаружить в разрезе «Широковский». В конце венда вся Волго-Уральская антеклиза испытывает поднятие, становится сушей и остается такой до девонского периода. Поэтому здесь отсутствуют кембрийские, ордовикские и силурийские отложения. 


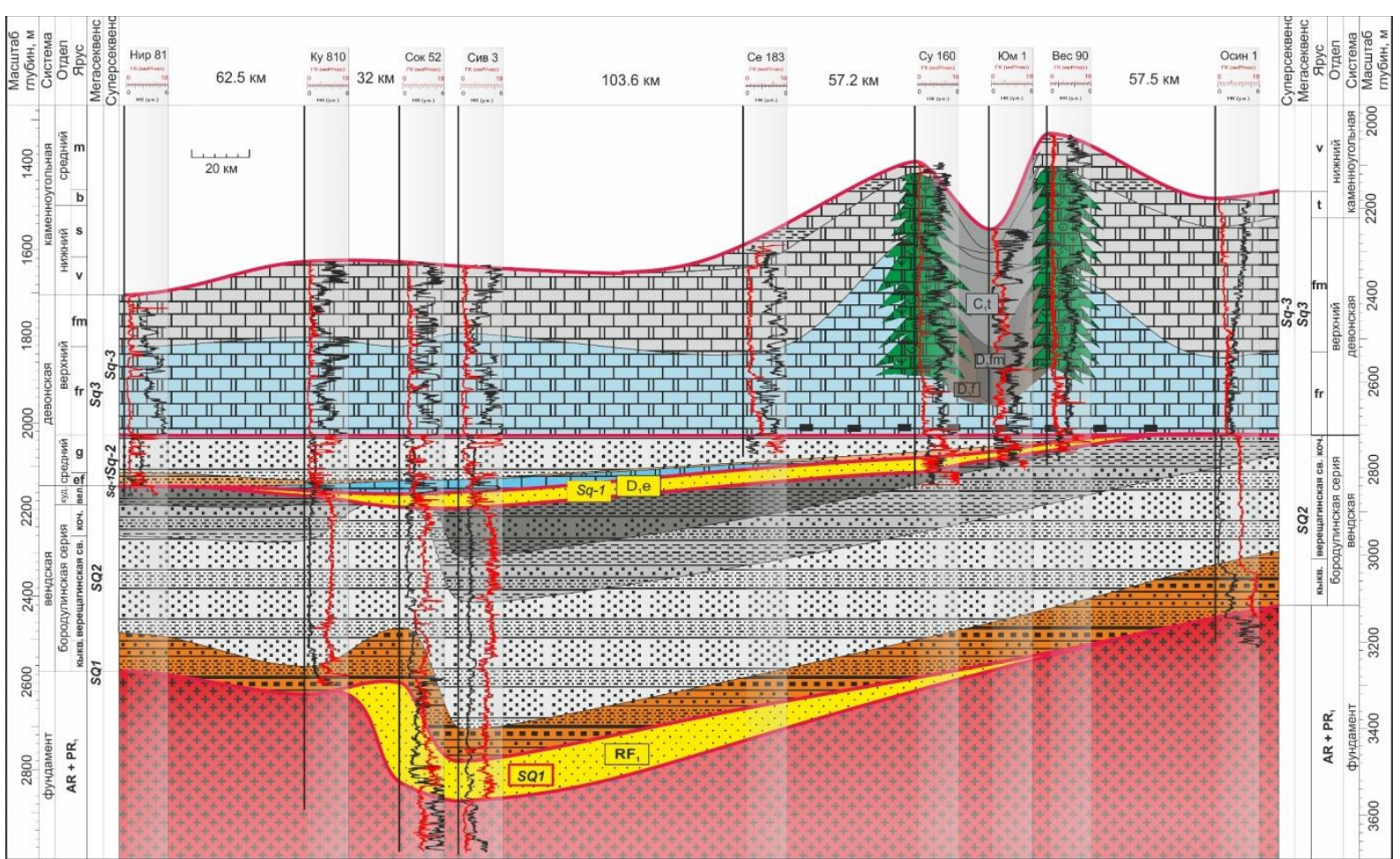

Pис. 5. Секвенс-стратиграфический профиль SQ1-3 по линии скважин Нир 81, Ку 810, Сок 52, Сив 3, Се 183, Су 160, Юм 1, Вес 90, Осин 1

Fig. 5. Sequence-stratigraphic profile SQ1-3 along the line of wells Hup 81, Ky 810, Сок 52, Сив 3, Ce 183, Cy 160, Юм 1, Вес 90, Осин 1

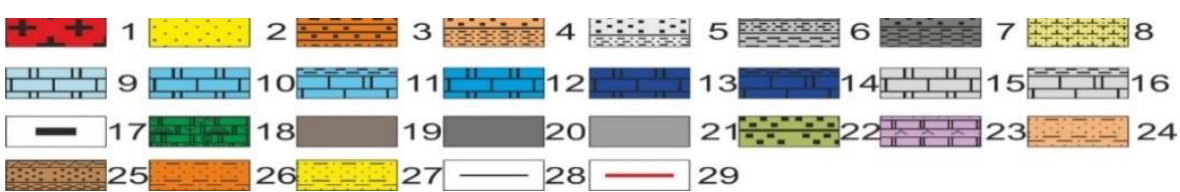

Pис. 6. Условные обозначения к секвенс-стратиграфическим профилям на рис. 5, 7, 8: 1) гранито-гнейсы фундамента; 2) континентальные терригенные отложения; 3) гравелитово-песчаниково-алевролитовые континентальные и переходные отложения; 4) песчаниково-алевролитовые отложения супралиторали и литорали; 5) алевролитово-песчаниковые отложения литорали; 6) песчаниково-алевролитово-глинистые отложения сублиторали; 7) песчаниково-глинистые отложения сублиторали; 8) смешанные терригенно-карбонатные отложения литорали; 9) карбонатные отложения супралиторали и литорали; 10) карбонатные отложения супралиторали и верхней литорали; 11) глинисто-карбонатные отложения супралиторали и верхней литорали; 12) карбонатные отложения литорали; 13) карбонатные отложения нижней литорали; 14) глинистокарбонатные отложения нижней литорали; 15) карбонатные отложения сублиторали; 16) глинистокарбонатные отложения сублиторали; 17) карбонатные отложения верхней сублиторали; 18) битуминозные известняки и доломиты сублиторали; 19) водорослево-микробиальные рифы; 20) кремнистобитуминозно-карбонатные отложения франского яруса; 21) битуминозно-глинисто-карбонатные отложения фаменского яруса; 22) карбонатно-глинистые отложения турнейского яруса; 23) терригенная моласса; 24) сульфатно-карбонатные отложения эвапоритового комплекса; 25) глинисто-песчаниковые дельтовые отложения; 26) мергельно-песчаниково-глинистые лагунные и приливно-отливные отложения; 27) глинисто-песчаниковые переходные отложения; 28) глинисто-песчаниковые континентальные отложения; 29) формационные границы; 30) границы секвенсов

Fig. 6. Legend for sequence-stratigraphic profiles in Fig. 5, 7, 8: 1) granite-gneisses of the basement; 2) continental terrigenous deposits; 3) gravelly-sandy-siltstone continental and transitional deposits; 4) sandy-siltstone deposits of the supralitoral and littoral; 5) silt-sandy deposits of the littoral; 6) sandy-silt-clayey sediments of the sublittoral; 7) sandy-clayey deposits of the sublittoral; 8) mixed terrigenous-carbonate sediments of the littoral; 9) carbonate deposits of the supralittoral and littoral; 10) carbonate deposits of the supralittoral and upper littoral; 11) claycarbonate deposits of the supralittoral and upper littoral; 12) carbonate deposits of the littoral; 13) carbonate deposits of the lower littoral; 14) clay-carbonate deposits of the lower littoral; 15) carbonate sediments of the sublittoral; 16) clay-carbonate sediments of the sublittoral; 17) carbonate deposits of the upper sublittoral; 18) bituminous limestones and dolomites of the sublittoral; 19) algal-microbial reefs; 20) siliceous-bituminous-carbonate deposits of the Frankish stage; 21) bituminous-clayey-carbonate deposits of the Famennian stage; 22) carbonateclayey deposits of the Tournaisian stage; 23) terrigenous molasse; 24) sulfate-carbonate deposits of the evaporite complex; 25) clay-sandy delta deposits; 26) marl-sandy-argillaceous lagoon and tidal deposits; 27) clay-sandy transitional deposits; 28) clay-sandy continental deposits; 29) formational boundaries; 30) sequence boundaries 
SQ3 соответствует плитному этапу формирования осадочного чехла (нижнедевонско-нижнекаменноугольный (турнейский) стратиграфический интервал). Подошва секвенса по керну снизу вверх представлена переходом от метаморфизированных аргиллитов и алевролитов зеленовато-серых и вишнево-коричневых, тонкослойчатых, плотных верхнего венда к терригенным или карбонатным отложениям нижнего или среднего девона. По каротажным диаграммам это граница, ниже которой резко возрастают показания ГК и падают значения НГК, что характеризует параметры пород венда (рис. 5). В составе секвенса были выделены следующие секвенсы второго порядка:

Sq1 выделяется в объеме такатинского и койвинского горизонтов верхней части эмского яруса $\mathrm{D}_{1} \mathrm{e}_{2}$. Осадконакопление в это время происходило преимущественно в условиях флювиальной и дельтовой равнины. На ТНС и ТСТ формировалась врезанная флювиальная равнина, терригенный материал поступал с северо-западных и западных территорий. В течение ТВC формируются разнообразные дельты вдоль западного склона Урала в месте разгрузки рек в мелководно-морской бассейн. В основании секвенса - кора выветривания, сложенная гравелитами и конгломератами. На крайнем западе и востоке профиля отложения $\mathbf{S q 1}$ выклиниваются (рис. 5).

Sq2 выделяется в объеме койвинского горизонта эмского яруса $\mathrm{D}_{1} \mathrm{e}_{2}$, эйфельского и живетского ярусов $\mathrm{D}_{2}$ и нижнефранского подъяруса $\mathrm{D}_{3} \mathrm{f}_{1}$. На востоке профиля секвенс выклинивается ввиду перерыва в осадконакоплении между верхним вендом и среднефранским подъярусом. В районе скважин $10,52,3$, 183 в эйфельском веке существовал мелководноморской бассейн, здесь накапливались карбонатные отложения супралиторали и верхней литорали, в районе других скважин - песчаниково-алевролитовые отложения супралиторали и литорали (ТНС и ТСТ), выше по разрезу перекрывающиеся главным образом алевролитово-песчаниковыми и карбонатными отложениями литорали ТВС. Отложения секвенса можно увидеть в разрезе «Хорошевка».

$\mathbf{S q 3}$ - отложения верхнедевонско-турнейского комплекса охватывают стратиграфический интервал от саргаевского горизонта среднефранского подъяруса верхнего девона до кизеловского горизонта верхнетурнейского подъяруса нижнего карбона. Осадконакопление контролировалось разнообразной геоморфологией морского дна: от крайнего мелководья, бортовых и депрессионных зон Камско-Кеннельской системы прогибов до изолированных мозаичных карбонатных платформ, что соответствует внутреннему и внешнему шельфу. Выделены следующие этапы развития. ОШТ - в это время в зоне супралиторали и литорали формировались карбонатно-сульфатные и карбонатные породы с единичными мелкими микробиальными карбонатными образованиями. В зоне сублиторали откладывались глинисто-карбонатные породы. На этапе ТСТ геоморфология дна значительно менялась. Более выраженными стали зоны прогибов с карбонатно-глинистым осадконакоплением. На бортовых зонах стали активно расти водорослево- микробиальные рифы, что способствовало формированию тыловой части карбонатной отмели платформы. На этапе ТВС значительно увеличилась скорость осадконакопления. Накопление доманикоидных пород определенно связано с некомпенсированной морской седиментацией в глубоководных участках шельфа (линейных или изометричных). При этом доманикоидные породы условий максимального затопления характеризуются повышенной кремнистостью, начала и середины ТВС - большей карбонатностью и карбонатными мегаконкрециями, а финальные отложения ТВС - появлением глинистых прослоев, свидетельствующих о начинающемся обмелении. Отложения проградирующей террасы накапливались исключительно у подножия мелкого шельфа при понижениях относительного уровня моря. Специфика состава, структурно-текстурные особенности, характерные группы ископаемых организмов указывают на то, что седиментогенез подобных образований происходил при выносе за бровку мелководного шельфа тонкого глинистого и карбонатного материала, содержащего мелкий органогенный детрит.

Верхнедевонско-турнейский карбонатный комплекс, в отличие от девонского терригенного, формировался в условиях относительно стабильного, но дифференцированного погружения крупных блоков, что обусловило разнообразие осадконакопления в морском бассейне. $\mathrm{B}$ результате тектоноседиментационных особенностей развития к концу франского века возникла ККСП, пересекающая территорию края с юго-запада на север в виде сопряженных депрессий. В прогибах, не компенсированных осадками, существовала застойная обстановка с сероводородным заражением придонных слоев воды. К концу франского века глубина моря в прогибах достигала 200-400 м. В них накапливались маломощные глинисто-кремнисто-битуминозные известковистые осадки доманикового типа. Все прогибы Камско-Кинельской системы обрамлены цепочками позднедевонских биогермных сооружений (рифов), над отдельными вершинами которых при последующем осадконакоплении возникли структуры облекания. Внутри прогибов на ограниченных по площади приподнятых участках, при соответствующей благоприятной фациальной обстановке, сформировались атоллоподобные и одиночные рифогенные сооружения. Обширные выступы в плане кровли терригенного девона послужили цоколем, над которым образовывались рифовые массивы типа атоллов. К началу турнейского века палеорельеф был весьма контрастно расчленен. Перепад глубин в зонах ККСП и прибортовых участках составлял 450-500 м. Прогибание с начала века существенно замедлилось и наступило время интенсивной компенсации прогибов. Заполнение прогибов происходило от бортов к осевым зонам в процессе размыва краевых палеошельфовых и рифогенных участков. Обломочный материал поступал в глубоководные районы шельфа, постепенно заполняя прогиб. Это выразилось накоплением мощных, до 300 м, дельтообразно построенных толщ клиноформ, представленных карбонатными, карбонатно- 
глинистыми или преимущественно глинистыми осадками. Чем моложе толща заполнения прогибов, тем в большей степени в ней преобладают терригенные осадки. Фаменские органогенные постройки можно обнаружить в разрезе «Пашийский Гребешок», отложения доманикоидного типа - в разрезе «Ядро», турнейского яруса - в разрезе «Губаха».

Секвенс SQ4 охватывает стратиграфический интервал от косьвинского горизонта визейского яруса до ассельского яруса нижней перми. Подошва се- квенса соответствует резко выраженному контакту карбонатных и терригенных пород, который отчетливо устанавливается по керну (турнейские известняки светло-серые, мелкозернистые и среднезернистые, плотные перекрываются радаевскими аргиллитами и алевролитами темно-серыми до черных средней плотности) и по каротажным диаграммам: граница, ниже которой резко возрастают показания НК и падают показания ГК. Были выделены следующие секвенсы второго порядка (рис. 7).

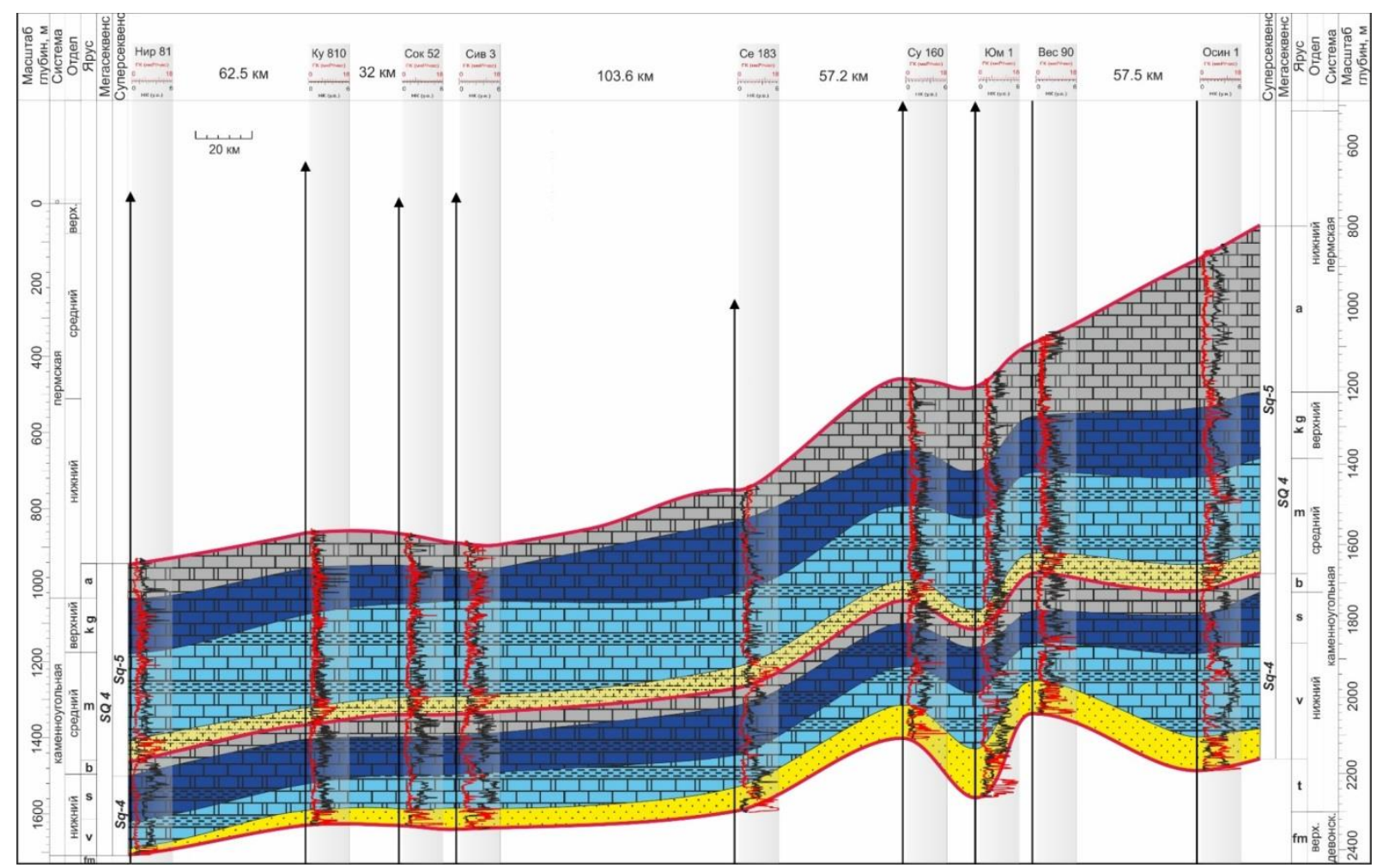

Pис. 7. Секвенс-стратиграфический профиль SQ4 по линии скважин Нир 81, Ку 810, Сок 52, Сив 3, Се 183, Су 160, Юм 1, Вес 90, Осин 1

Fig. 7. Sequence-stratigraphic profile SQ4 along the line of wells Hup 81, Ky 810, Сок 52, Сив 3, Се 183, Су 160, Юм 1, Вес 90, Осин 1

Sq4 выделяется в объеме визейского и серпуховского ярусов нижнего карбона и башкирского яруса среднего карбона. ТНС представлен терригенными флювиальными и дельтовыми отложениями, которые можно обнаружить в разрезе «Каменный город». В это время терригенный материал поступал с северозапада на юго-восток. ТСТ и ТВС представлены глинисто-карбонатными отложениями супралиторали и верхней литорали, вверх по разрезу переходящими в глинисто-карбонатные отложения нижней литорали, и глинисто-карбонатными отложениями сублиторали. В визейском веке, по сравнению с турнейским, палеогеографическая обстановка существенно меняется. На всей территории Пермского края устанавливаются прибрежно-морские и прибрежно-континентальные обстановки, что способствует накоплению в основном терригенных и в меньшей степени карбонатнотерригенных и терригенно-карбонатных осадков. Камско-Кинельская система прогибов в значительной степени нивелируется. Прогибы сохраняются лишь в центральных приосевых ее частях. Количество обломочного материала, поступавшего с суши, было вполне достаточным для компенсации продолжавшегося прогибания рассматриваемой территории. Флювиально-дельтовые фации преобладают в радаевских, бобриковских и в нижней части тульских отложений, а в плане - в обширной центральной полосе, протянувшейся с северо-востока на юго-запад и соответствующей ККСП и ее рукавам. Для поздневизейскобашкирского времени характерна нестабильность тектонической обстановки осадконакопления: трансгрессия, охватившая практически всю территорию края в алексинское время, сменяется регрессией моря, начавшейся в конце серпуховского века и продолжавшейся до середины башкирского. Затем регрессия вновь сменяется трансгрессией, продлившейся до конца башкирского времени. В конце башкирского века происходит общий подъем территории с образованием суши на многих участках, приведший к размыву части башкирских отложений. 
Sq5 представлен московским ярусом среднего карбона, нерасчлененными касимовским и гжельским ярусами верхнего карбона, ассельским ярусом нижней перми. Московский век знаменует собой новый этап в истории геологического развития - карбонатный седиментогенез сменяется терригеннокарбонатным, затем карбонатным. Доля карбонатных осадков повсюду резко сократилась, а вынос терригенного материала с площадей размыва значительно увеличился. В верейское время на большей части территории Пермского края существовал унаследованный от башкирского века мелководный морской бассейн, в котором ритмически накапливались глинистые и известковые илы. ТНС обуславливал формирование смешанных терригенно-карбонатных отложений на литорали. Терригенный материал поступал с территории современного Урала. ТСТ и ТВС представлен переходом от глинисто-карбонатных отложений супралиторали и верхней литорали до карбонатных отложений литорали и сублиторали. Вверх по разрезу возрастает сульфатизация пород, в верхнем карбоне и ассельском ярусе породы сложены сульфатизированными доломитами с тонкими прослоями ангидритов. Породы среднего и верхнего карбона можно увидеть в разрезе «Орёл».

Sq6 выделен в объеме сакмарского, артинского и кунгурского ярусов нижней перми. ОШТ представлен карбонатныли отложениями супралиторали и верхней литорали. На этапе ТСТ и ранней стадии ТВС происходит трансгрессия моря, что способствовало активному росту рифов. Артинские рифы можно обнаружить в разрезе «Чикали». Формирование отложений происходит главным образом на нижней литорали и верхней сублиторали. В артинское время под действием активного роста Урала формируется пермская моласса, которая представлена карбонатнообломочными породами так называемого «терригенного клина». Терригенный материал поставлялся речными потоками с Уральских гор, поэтому в восточном направлении возрастала его грубозернистость и в разрезах осадочных толщ появлялись конгломераты с гальками уральских пород. Данные отложения представлены в разрезе «Травянка». В кунгурский век отчетливо прослеживается дальнейший переход от нормального морского режима осадконакопления, доминировавшего главным образом на литорали, к мелководно-морским, прибрежно-морским и лагунным обстановкам с преобладанием последних на поздней стадии ТВС, начавшейся в артинский век на западе территории. Следует подчеркнуть, что на этапе $\mathrm{TBC}$ на большей западной платформенной части территории формировались сульфатнокарбонатные, а в меньшей, восточной - карбонатносульфатные отложения со значительным нарастанием их мощности. Однако максимальное осадконакопление происходит в центральной части Предуральского прогиба, который практически полностью нивелируется. К западному борту прогиба было приурочено мергельно-карбонатно-сульфатное осадконакопление. В центральной, наиболее глубокой, части Соликамской впадины происходило формирование мощной глинисто-сульфатно-галогенной толщи уникального Верхнекамского соляного месторождения. К востоку от него и южнее зоны мергельно-карбонатно-сульфатных отложений, в прибрежно-морских мелководных условиях накапливались сульфатно-карбонатно-глинистые отложения поповской свиты с прослоями солей, сменявшиеся к востоку сульфатно-терригенными образованиями кошелевской свиты с прослоями солей. Нивелирование впадин этого прогиба эвапоритовым комплексом осадков было знаменательным событием в истории геологического развития территории, означавшим грядущее наступление континентального режима развития Среднего Приуралья. Карбонатно-сульфатные отложения кунгурского яруса и границу кунгурского и уфимского ярусов можно проследить в разрезах «Залесная» и «Чумкасский карьер».

Sq7 выделен в составе уфимского яруса нижней перми, казанского и уржумского ярусов средней перми, нерасчлененных северодвинского и вятского ярусов верхней перми. Позднепермская эпоха развития территории характеризуется ускоренным переходом к преобладанию континентального режима осадконакопления. В начале уфимского века еще сохранился мелководный морской бассейн, унаследованный от иренского времени. Бассейн активно опреснялся уральскими реками, и уже к концу уфимского века был сформирован флювиально-дельтовый комплекс отложений ТНС. Среднепермское время ознаменовалось переходом от прибрежно-морских к континентальным условиям осадконакопления ТСТ.

В позднепермское время осадконакопление происходило в условиях континентальной равнины: продолжалось накопление песчаниково-глинистых и конгломератовых отложений с прослоями озерных карбонатов. Красноцветные терригенные отложения можно обнаружить в разрезе «Самосадка».

Таким образом, построенные и проанализированные разрезы осадочного чехла (рис. $5,7,8$ ) показывают смену условий осадконакопления и особенности развития осадочного бассейна. Выделенные мега- и суперсеквенсы являются базой для более детальных секвенсстратиграфических исследований. Анализ стал основой для построения кривой колебания уровня моря.

\section{Характеристика эвстатических колебаний}

Для наглядной характеристики колебаний уровня моря в процессе геологического развития северовосточной части ВЕП была построена эвстатическая кривая, сопряженная с районом регионального геологического профиля. Для этого прорабатывалась современная литература по эвстатическому анализу [22], результаты работы международных групп по фанерозою [23-30]. Эвстатическая кривая построена на основе анализа изменения пространственно-временного распространения свит и толщ осадочного чехла и ранжирования выделенных поверхностей максимумов и минимумов относительных уровней моря. Построенная диаграмма удачно отражает секвенсстратиграфическое расчленение рассматриваемых отложений с выделением фациальной зональности отложений (рис. 9). 


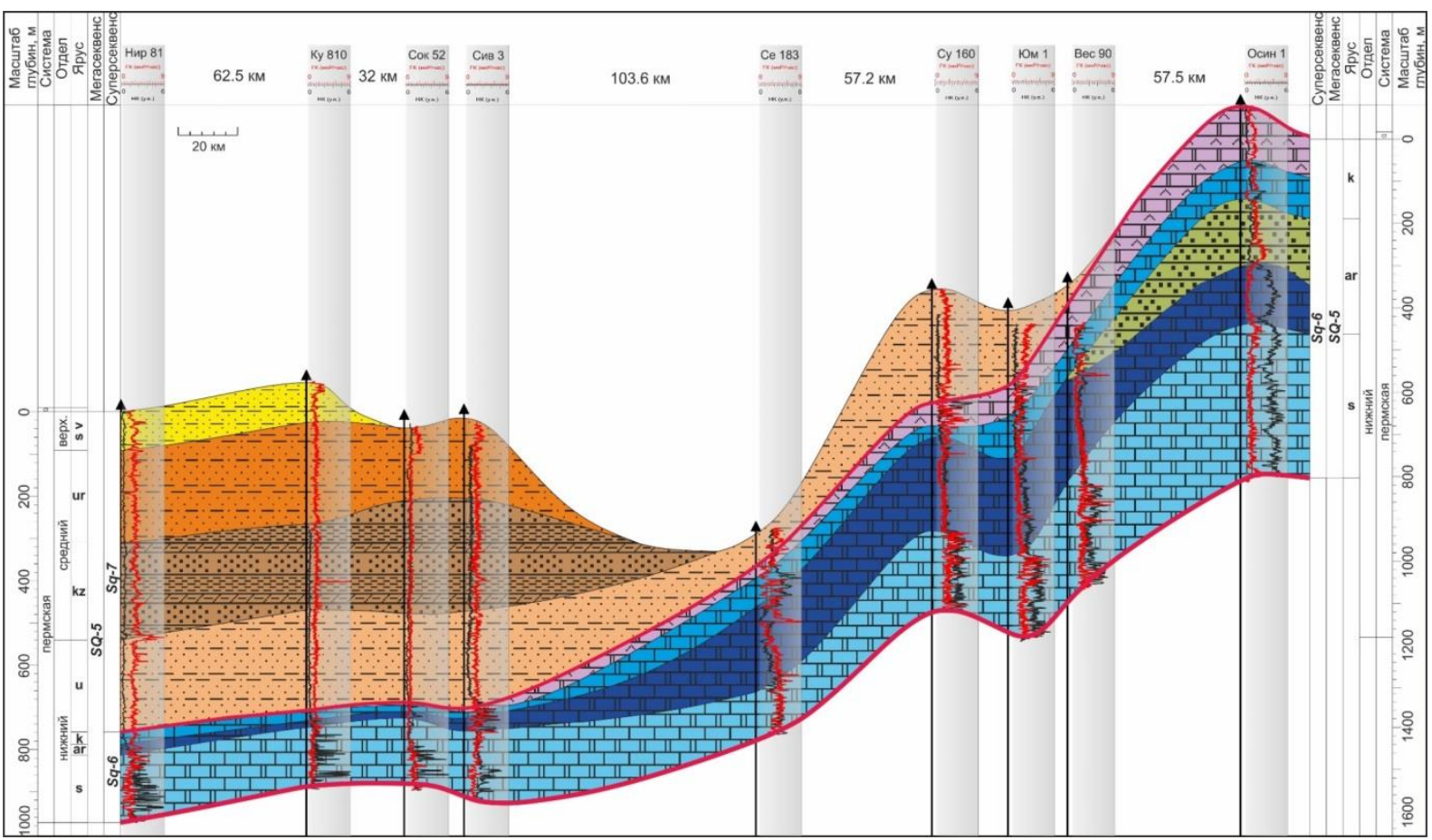

Pис. 8. Секвенс-стратиграфический профиль SQ5 по линии скважин Нир 81, Ку 810, Сок 52, Сив 3, Се 183, Су 160, Юм 1, Вес 90, Осин 1

Fig. 8. Sequence-stratigraphic profile SQ5 along the line of wells Hup 81, Ky 810, Сок 52, Сив 3, Се 183, Cy 160, Юм 1, Вес 90, Осин1

Построенная для локального участка субширотного регионального профиля эвстатическая кривая сопряжена как с общей стратиграфической (геохронологической) шкалой, так и с глобальной кривой изменений уровня моря [30]. Ее резкая дифференциация указывает на относительные колебания уровня моря на северовосточной окраине ВЕП по сравнению с малоамплитудностью глобальной кривой в крайнем правом столбце и вызвана различными масштабами отображения детальных и глобальных процессов этих колебаний.

Следует отметить, что северо-восточная окраина ВЕП характеризуется высокой эпейрогенической активностью, вызванной процессами, происходившими в смежной Уральской палеоокеанической системе. Континентальный рифтогенез в Волго-Уральской области платформы носил характер омоложения более древних структур, особенно в раннегерцинское время. Значительные перерывы в осадконакоплении на восточной периферии платформы (в докембрии, нижнем палеозое и в мезозое) приурочены к моментам изменения ее напряженного состояния и последующим тектоническим воздыманиям её окраинных частей.

Показания и цикличность колебаний эвстатической кривой с её локальными максимумами и минимумами, связанными с образованием соответствующих фациальных комплексов, отображены в хронологической последовательности, в формате воздымания кривой.

1. Рифей-венд. На этом этапе вверх по разрезу отмечается неравномерная миграция кривой в сторону подъема уровня моря от континентальных (аллювиальных и пролювиальных) отложений до песчано- глинистых мелководно-морских образований сублиторали с сопутствующими перерывами в осадконакоплении $\left(\mathrm{RF}_{2}+\mathrm{RF}_{3}+\mathrm{V}_{1}\right)$.

Далее, после верхнего венда, эвстатическая кривая для данной территории прерывается на геохронологический срок порядка 140 млн лет в связи с перерывом осадконакопления в кембрийском, ордовикском, силурийском периодах, вплоть до позднеэмского времени раннего девона.

2. Нижний и средний девон $\left(\mathrm{D}_{1}+\mathrm{D}_{2}\right)$. Эвстатическая кривая в позднеэмско-раннеэйфельское время локальным полумаксимумом подъема уровня отображает переход от прибрежно-морских фаций до мелководно-морских, с накоплением над корой выветривания песчаниково-глинистых отложений и частично карбонатных пород. В позднеэйфельское время отмечается краткая регрессия моря с накоплением прибрежно-морских терригенных осадков в период $\mathrm{D}_{2} \mathrm{~g}-\mathrm{D}_{3} \mathrm{f}_{1}$, после чего кривая переходит в режим постоянного подъема уровня моря.

3. Верхний девон и турнейский ярус нижнего карбона $\left(\mathbf{D}_{3} \mathbf{f}_{2}+\mathbf{C} 1 \mathbf{t}\right)$. В этом длительном временном интервале от саргаевского горизонта франского яруса до подошвы отложений визейского яруса нижнего карбона эвстатическая кривая отображает высокие уровни стояния моря с небольшими временными регрессиями и с образованием мелководно-морских, нормально-морских и глубоководно-морских карбонатных осадков. Наибольшего максимума обширная трансгрессия достигает в позднефранско-фаменское время. К концу турнейского века проявляются признаки наступающего обмеления моря. 


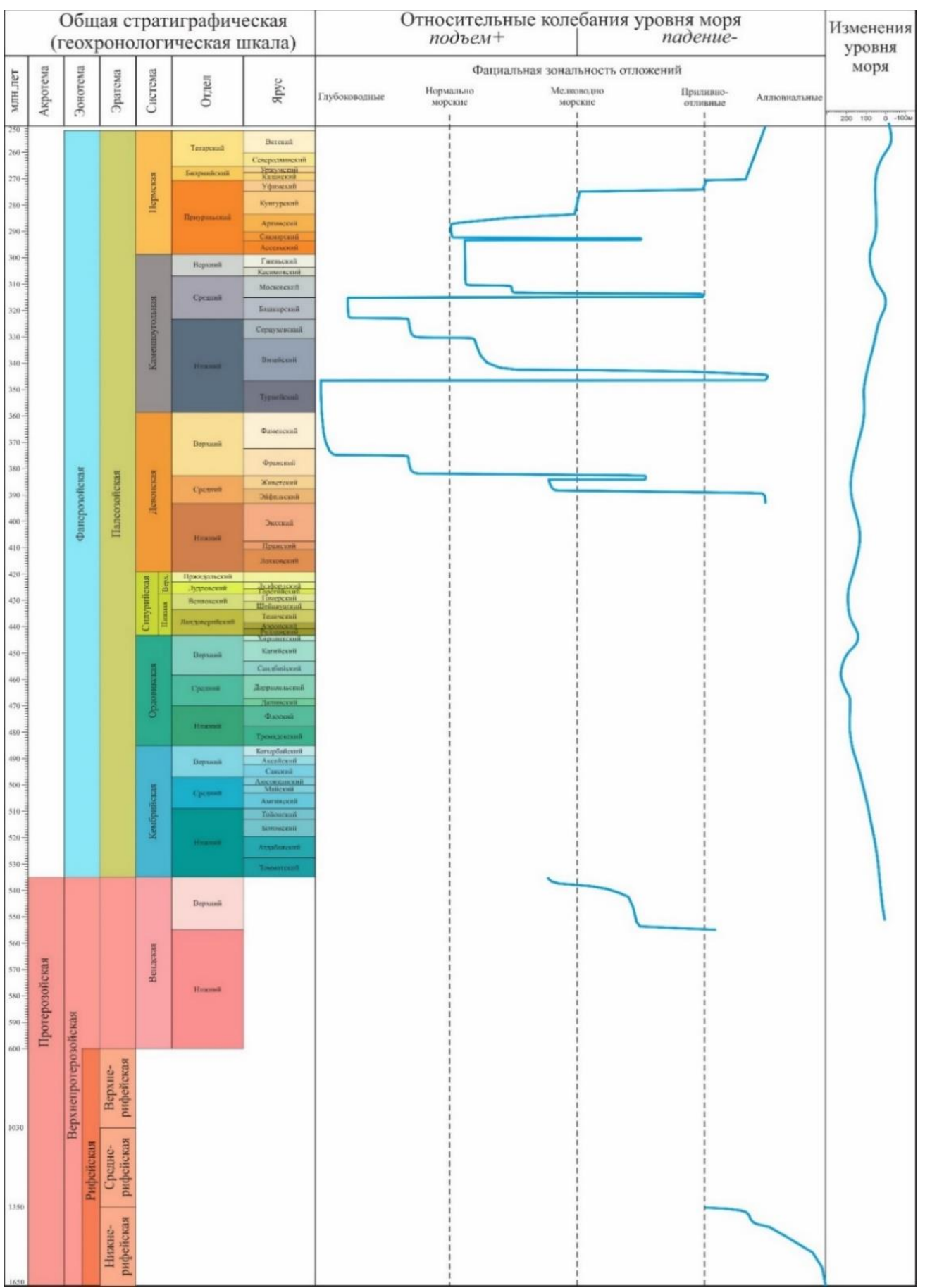

Рис. 9. График эвстатических колебаний уровня моря осадочного чехла для северо- востока Восточно-Европейской платформы в сопоставлении с международной глобальной кривой изменений уровня моря [30]

Fig. 9. Plot of eustatic sea level fluctuations in the sedimentary cover for the northeast of the East European platform in comparison with the international global sea level curve [30]

4. Нижний, средний и верхний карбон $\left(\mathrm{C}_{1} \mathrm{v}+\mathrm{C}_{3}\right)$. В ранневизейское время кривая фиксирует региональный локальный минимум, сопряженный с прибрежно-морскими и прибрежно-континентальными обстановками, где происходило накопление аллювиально-дельтовых фаций.

В поздневизейско-раннесерпуховское время отмечается трансгрессия моря, сменившаяся кратковременной регрессией в позднесерпуховское-раннебашкирское время.
Для позднебашкирского времени кривая снова отображает краткое повышение уровня моря, сменившееся в раннемосковском временном интервале (верейское время) резким понижением его уровня и, в связи с подъемом суши, образованием мелководного морского бассейна, в котором циклично накапливались глинистые и известковые илы.

Позже, для московского века и каменноугольной эпохи, отмечается достаточно высокий уровень моря с нормальным карбонатным осадконакоплением, а в 
конце цикла - с образованием мелководных лагун с сульфатно-карбонатными осадками.

5. Нижняя пермь $\left(\mathbf{P}_{\mathbf{1}} \mathbf{a}+\mathbf{s}+\mathbf{a r}+\mathbf{k}+\mathbf{u}\right)$. В нижнепермскую эпоху продолжился режим среднего стояния уровня моря в ассельский век и сульфатнокарбонатного седиментогенеза. Переход от ассельского века к сакмарскому характеризуется кратковременным (около 1-1,5 млн лет) локальным минимумом кривой уровня моря за счет заполнения мелководных лагун сульфатно-карбонатным материалом. В сакмарском веке и в раннеартинское время наблюдается относительно средний уровень стояния моря, тогда как в позднеартинское время эвстатическая кривая фиксирует падение уровня моря и преобладание морских мелководных обстановок с лагунным типом осадконакопления. В последующее - кунгурское и раннеуфимское - время доминируют эвапоритовые лагуны, периодически опресняемые континентальными реками.

В позднеуфимское время кривая отображает переход от низкого стояния уровня моря к его полному обмелению с образованием прибрежной аллювиальной равнины.

6. Средняя и верхняя пермь (биармийский и татарский отделы). Заключительный верхний отрезок эвстатической кривой отмечает минимальные показания, характерные для обстановки прибрежной континентальной равнины.

Цикличность колебаний эвстатической кривой, построенной для конкретного регионального профиля северо-восточной части ВЕП, в целом не противоречит основным трендам расчетных колебаний уровня моря по сглаженной глобальной кривой (рис. 9).

Таким же образом характер колебаний уровня моря, отображенный для восточного участка перифе-

\section{СПИСОК ЛИТЕРАТУРЫ}

1. Bogdanova S.V. The three-segment hypothesis for the East European Craton. - Strasbourg: Terra Nova, 1993. - 313 p.

2. Лядова Н.А. Яковлев Ю.А., Распопов А.В. Геология и разработка нефтяных месторождений Пермского края. - М. ВНИИОЭНГ, 2010. $-335 \mathrm{c}$.

3. Неганов В.М. Сейсмогеологическая интерпретация геофизических материалов Среднего Приуралья и перспективы дальнейших исследований на нефть и газ. - Пермь: Пермский государственный университет, 2010. -248 c.

4. Сулима А.И. Геология и нефтегазоносность верхнедевонскотурнейского карбонатного комплекса юго-востока Пермского края // Нефтяное хозяйство. - 2011. - № 10. - С. 44-48.

5. Аксенов Е.М., Козлов В.И. Стратиграфическая схема рифейских и вендских отложений Волго-Уральской области Объяснительная записка. - Уфа: ИГ УНЦ РАН, 2000. - 81 с.

6. Унифицированная субрегиональная стратиграфическая схема верхнедевонских отложений Волго-Уральского субрегиона. Объяснительная записка / Н.К. Фортунатова, Е.Л. Зайцева, М.А. Бушуева, А.Г. Швец-Тэнэта-Гурий, А.В. Баранова, Л.И. Кононова, Е.В. Рахимова, А.И. Михеева, Н.В. Оленева, А.А. Авдеева. - М.: ВНИГНИ, 2018. - 63 с.

7. Кагарманов А.Х., Донакова Л.М. Решение Межведомственного регионального стратиграфического совещания по среднему и верхнему палеозою Русской платформы с региональными стратиграфическими схемами. Каменноугольная система. - Л. ВСЕГЕИ, 1990. - $40 \mathrm{c}$

8. Горский В.П., Гусева Е.А. Решение Межведомственного регионального стратиграфического совещания по среднему и верхнему палеозою Русской платформы с региональными рийной части ВЕП, соответствует результатам проведенных секвенс-стратиграфических исследований.

\section{Заключение}

Проведение комплексного обобщения данных глубокого бурения и полевых наблюдений геологических разрезов позволило с позиций секвенсстратиграфического анализа выделить и описать пять секвенсов первого порядка (мегасеквенсы), сменяющих друг друга снизу вверх: SQ1, соответствующий рифейскому этапу; SQ2, соответствующий вендскому этапу; SQ3, нижнедевонско-турнейский; SQ4, визейско-нижнепермский; SQ5, нижнепермскийверхнепермский. Мегасеквенсы, в свою очередь, были разделены на секвенсы второго порядка (суперсеквенсы): Sq1 - нижнедевонский; Sq2 - нижнедевонско-нижнефранский; $\mathrm{Sq} 3$ - среднефранскотурнейский; Sq4 - визейско-башкирский; Sq5 - московско-ассельский; $\mathrm{Sq} 6$ - сакмарско-кунгурский; $\mathrm{Sq} 7$ - уфимско-верхнепермский. К границам секвенсов приурочены стратиграфические перерывы разной продолжительности. Самыми длительными являются перерывы между нижним рифеем и верхним вендом, а также верхним вендом и нижним девоном. Секвенсстратиграфический анализ позволил впервые построить эвстатическую кривую для данного района. Максимальные регрессии пришлись на эмский, визейский и московский века и на средне-позднепермскую эпохи. К ним приурочен ТНС и основные терригенные коллекторы. Максимальные трансгрессии отмечены в фаменский, турнейский, башкирский ассельский века. К ним приурочены органогенные постройки, формировавшиеся на ТВС. Таким образом прослежена геологическая история осадконакопления северо-востока Восточно-Европейской платформы.

стратиграфическими схемами. Пермская система. - Л.: ВСЕГЕИ, 1990. - 48 с.

9. Posamentier H.W., Allen G.P. Siliciclastic sequence stratigraphy: concepts and applications // SEPM, Concepts in Sedimentology and Paleontology 1999. - V. 7. - 210 p.

10. Einsele G. Sedimentary basins: Evolution, facies and sediment budget. - Heidelberg: Springer-Verlag, 2000. - 792 p.

11. Catuneanu O. Sequence stratigraphy of clastic systems: concepts, merits, and pitfalls // Journal of African Earth Sciences. - 2002. V. 35. - P. 1-43.

12. Пучков В.Н., Козлов В.И. Особенности тектоники ВолгоУральской нефтегазоносной области // Георесурсы. - 2005. T. 16. - № 1. - C. 24-27.

13. Artyushkov E.V., Baer M. Mechanism of formation of hydrocarbon basins: the West Siberia, Volga-Urals, TimanPechora basins and the Permian Basin of Texas // Tectonophysics. - 1986. - № 122. - Р. 247-281.

14. Алиев М.М. Геология и нефтегазоносность рифейских и вендских отложений Волго-Уральской провинции. - М.: Наука, 1977. $-157 \mathrm{c}$

15. Лозин Е.В. Глубинное строение и нефтегазоносность ВолгоУральской области и смежных территорий // Литосфера. 2002. - № 3. - С. 46-68.

16. Сулима А.И. Новые данные о геологическом строении и нефтегазоносности юго-восточных территорий Пермского края // Геология и нефтегазоносность северных районов Урало-Поволжья: Материалы Всероссийской научнопрактической конференции, посвященной 100-летию со дня рождения профессора П.А. Софроницкого. - Пермь: Пермский государственный университет, 2010. - С. 270-275 
17. Read J. Carbonate platform facies models // AAPG Bulletin. 1985. - № 69. - P. 1-21.

18. Sedimentary characteristics and evolution of Domanik facies from the Devonian-Carboniferous regression in the southern VolgaUral Basin / X. Liang, Z. Jin, V. Philippov, O. Obryadchikov, D. Zhong, Q. Liu, B. Uspensky, V.P. Morozov // Marine and Petroleum Geology. - 2020. - № 119. - P. 1-12.

19. Late Paleozoic seismic sequence stratigraphy and paleogeography of the paleo-Loppa High in the Norwegian Barents Sea / J. Sayago, M. di Luccia, M. Mutti, A. Sitta, A. Cotti, G. Frijia // Marine and Petroleum Geology. - 1997. - V. 97. - P. 192-208.

20. Burchette T., Wright V. Carbonate ramp depositional systems // Sedimentary Geology. - 1992. - № 79. - P. 3-57.

21. Facies and seismic analysis of the Late Carboniferous-Early Permian Finnmark carbonate platform (southern Norwegian Barents Sea): An assessment of the carbonate factories and depositional geometries / M. Lucia, J. Sayago, G. Frijia, A. Cotti, A. Sitta, M. Mutti // Marine and Petroleum Geology. - 2017. № 79. - P. 372-393.

22. Dott R. An introduction to the Ups and Downs of Eustasy. Eustasy: The Histroical Ups and Downs of a Major Geological Concept. Boulder // Geological Society of America Bulletin. - 1992. V. 1. - № 80. - P. 1-16.

23. Hallam A. Phanerozoic sea-level changes. - New York: Columbia University Press, 1992. $-266 \mathrm{p}$.

24. Ruban, D. A «chaos» of Phanerozoic eustatic curves // Journal of African Earth Sciences. - 2016. - № 116. - P. 225-232.
25. Temperature evolution and the oxygen isotope composition of Phanerozoic oceans from carbonate clumped isotope thermometry / G. Henkes, B. Passey, E. Grossman, B.J. Shenton, T. Yancey, A. Pérez-Huerta // Earth and Planetary Science Letters. - 2018. № 490. - P. 40-50.

26. Boulila S. Coupling between Grand cycles and Events in Earth's climate during the past 115 million years // Scientific Reports. 2019. - № 9. - P. 1-7.

27. Seawater temperature and dissolved oxygen over the past 500 million years / H. Song, P. Wignall, X. Dai, D. Chu // Journal of Earth Science. - 2019. - № 30. - P. 236-243.

28. The interplay of dynamic topography and eustasy on continental flooding in the late Paleozoic / W. Cao, N. Flament, S. Zahirovic, S.E. Williams, R.D. Muller // Tectonophysics. - 2019. - № 761. P. 108-121.

29. Kabanov P., Jiang C. Photic-zone euxinia and anoxic events in a Middle-Late Devonian shelfal sea of Panthalassan continental margin, NW Canada: Changing paradigm of Devonian ocean and sea level fluctuations // Global and Planetary Change. - 2020. № 188. - P. 1-19.

30. Snedden J.W., Liu C. A compilation of Phanerozoic sea level change, coastal onlaps, and recommended sequence designations // American Association of Petroleum Geologists Search and Discovery Article. $-2010 .-3$ p.

Поступила 28.10.2021 г.

\section{Информация об авторах}

Сулима А.И., соискатель кафедры региональной и нефтегазовой геологии Пермского государственного национального исследовательского университета.

Плюснин A.B., седиментолог, департамент геологии и разработки месторождений, ООО «ИНК».

Плешков Л.Д., старший преподаватель кафедры геофизики Пермского государственного национального исследовательского университета.

Tрубин Я.С., лаборант-исследователь лаборатории седиментологии и эволюции палеобиосферы Тюменского государственного университета.

Tимофеев В.Д., соискатель кафедры региональной и нефтегазовой геологии Пермского государственного национального исследовательского университета. 
UDC 551.7.001.5(4'7) (470.53)

\title{
STRUCTURE AND DEVELOPMENT STAGES OF THE NORTHEAST PART OF THE EAST EUROPEAN PLATFORM SEDIMENTARY BASIN IN THE PROTEROZOIC AND PALEOZOIC BASED ON LONG-TERM GEOLOGICAL SECTIONS OUTCROPS OBSERVATIONS AND STUDIES OF DEEP WELLS
}

\author{
Aleksandr I. Sulima1, \\ super.sulima2013@yandex.ru
}

Aleksey V. Plyusnin², A.V.Plyusnin@mail.ru

Lev D. Pleshkov1, levpleshkov@psu.ru

Yaroslav S. Trubin ${ }^{3}$, iyr-2009@mail.ru

\author{
Vladislav D. Timofeev ${ }^{1}$, \\ immrill@yandex.ru \\ 1 Perm State National Research University, \\ 15, Bukirev street, Perm, 614068, Russia. \\ 2 LLC «INK», \\ 4, Bolshoy Liteiny avenue, Irkutsk, 664007, Russia. \\ 3 Tyumen State University, \\ 6, Volodarsky street, Tyumen, 625003, Russia.
}

The relevance of the study is caused by the need to rethink the structure of the sedimentary cover in the northeast part of the East European Platform from the standpoint of sequence-stratigraphic analysis, which will make it possible to construct the eustatic curve and to become the basis for a more detailed study.

Purpose: dividing sediments into first and second order sequences and plotting a sea level fluctuation curve.

Objects: outcrops of the western slope of the Urals, and the northeast part of the East European and deep platform, deep wells of Nirimskaya, Kuliginskaya, Sokolovskaya, Sivinskaya, Severokamskaya, Sukhobizyarskaya, Yumyshskaya, Veslyanskaya and Osintsevskaya areas.

Methods: field work, cross-well correlation, lithological-facies, eustatic and basin analysis.

Results. The comprehensive generalization of deep drilling data and field observations of outcrops made it possible, from the standpoint of sequence-stratigraphic analysis, to identify and describe five first-order sequences (megasequences) following from bottom to top: Riphean; Vendian; Lower Devonian - Tournaisian; Visean - Lower Permian; Lower Permian - Upper Permian. Mega-sequences, in their turn, were divided into second-order sequences (super-sequences): Lower Devonian; Lower Devonian - Lower Frasnian; Middle Frasnian - Tournaisian; Visean - Bashkirian; Moscowian - Asselian; Sakmarian - Kungurian; Ufaimian - Upper Permian. Stratigraphic breaks of different duration are confined to the boundaries of the sequences. The longest ones are the intervals between the Lower Riphean and the Upper Vendian, as well as the Upper Vendian and the Lower Devonian. Sequential stratigraphic analysis allowed constructing a eustatic curve for a given area. The maximum regressions occurred in the Emskian, Visean, and Moscowian ages and in the Middle-Late Permian epoch. They are associated with a tract of low sea level (lowstand system tract) and the main terrigenous reservoirs. The maximum transgressions were noted in the Famennian, Tournaisian, Bashkirian Asselianian centuries. They are associated with organogenic structures, which were formed on the high sea level highstand system tract. Thus, the geological history of sedimentation in the northeast of the East European Platform is traced.

\section{Key words:}

Sequence stratigraphy, Upper Paleozoic, East European Platform, Volga-Ural oil and gas province,

Perm region, borehole correlation, lithological-facies analysis, eustatic analysis, basin analysis.

\section{REFERENCES}

1. Bogdanova S.V. The three-segment hypothesis for the East European Craton. Strasbourg, Terra Nova, 1993. 313 p.

2. Lyadova N.A. Yakovlev Yu.A., Raspopov A.V. Geologiya $i$ razrabotka neftyanykh mestorozhdeniy Permskogo kraya [Geology and development of oil fields in the Perm region]. Moscow, VNIIOENG Publ., 2010. 335 p.

3. Neganov V.M. Seysmogeologicheskaya interpretatsiya geofizicheskikh materialov Srednego Priuralya $i$ perspektivy dalneyshikh issledovaniy na neft $i$ gaz [Seismogeological interpretation of geophysical data from the Middle Urals and prospects for further research on oil and gas]. Perm, Perm State University Publ., 2010. 248 p.

4. Sulima A.I. Geology and oil and gas content of the Upper Devonian-Tournaisian carbonate complex in the southeast of the Perm region. Oil industry, 2011, no. 10, pp. 44-48. In Rus.

5. Aksenov E.M., Kozlov V.I. Stratigraficheskaya skhema rifeyskikh $i$ vendskikh otlozheniy Volgo-Uralskoy oblasti. Obyasnitelnaya zapiska [Stratigraphic diagram of the Riphean and Vendian deposits of the Volga-Ural region. Explanatory note]. Ufa, IG UC RAS Publ., 2000. 81 p. 
6. Fortunatova N.K., Zaytseva E.L., Bushueva M.A., Shvets-TenetaGuriy A.G., Baranova A.V., Kononova L.I., Rakhimova E.V., Mikheeva A.I., Oleneva N.V., Avdeeva A.A. Unifitsirovannaya subregionalnaya stratigraficheskaya skhema verkhnedevonskikh otlozheniy Volgo-Uralskogo subregiona. Obyasnitelnaya zapiska [Unified subregional stratigraphic scheme of the Upper Devonian deposits of the Volga-Ural subregion. Explanatory note]. Moscow, VNIGNI Publ., 2018. 63 p.

7. Kagarmanov A.H., Donakova L.M. Reshenie Mezhvedomstvennogo regionalnogo stratigraficheskogo soveshchaniya po srednemu $i$ verkhnemu paleozoyu Russkoy platformy s regionalnymi stratigraficheskimi skhemami. Kamennougolnaya sistema [Decision of the Interdepartmental Regional Stratigraphic Meeting on the Middle and Upper Paleozoic of the Russian Platform with regional stratigraphic schemes. Coal system]. Leningrad, VSEGEI Publ., 1990. 40 p.

8. Gorskiy V.P., Guseva E.A. Reshenie Mezhvedomstvennogo regionalnogo stratigraficheskogo soveshchaniya po srednemu verkhneтu paleozoyu Russkoy platformy s regionalnymi stratigraficheskimi skhemami. Permskaya Sistema [Decision of the Interdepartmental Regional Stratigraphic Meeting on the Middle and Upper Paleozoic of the Russian Platform with regional stratigraphic schemes. Permian system]. Leningrad, VSEGEI Publ. 1990. $48 \mathrm{p}$.

9. Posamentier H.W., Allen G.P. Siliciclastic sequence stratigraphy: concepts and applications. SEPM Concepts in Sedimentology and Paleontology, 1999, vol. 7, $210 \mathrm{p}$.

10. Einsele G. Sedimentary basins, evolution, facies and sediment budget. Heidelberg, Springer-Verlag, 2000. $792 \mathrm{p}$.

11. Catuneanu O. Sequence stratigraphy of clastic systems: concepts, merits, and pitfalls. Journal of African Earth Sciences, 2002, vol. 35 , pp. 1-43.

12. Puchkov V.N., Kozlov V.I. Peculiarities of tectonics of the VolgaUral oil and gas region. Georesursy, 2005, vol. 16, no. 1, pp. 24-27. In Rus.

13. Artyushkov E.V., Baer M. Mechanism of formation of hydrocarbon basins: the West Siberia, Volga-Urals, TimanPechora basins and the Permian Basin of Texas. Tectonophysics, 1986, no. 122, pp. 247-281.

14. Aliev M.M., Morozov S.T., Postnikova I.E. Geologiva neftegazonosnost rifeyskikh $i$ vendskikh otlozheniy Volgo-Uralskoy provintsii [Geology and oil and gas content of the Riphean and Vendian deposits of the Volga-Ural province]. Moscow, Nauka Publ., 1977. 157 p.

15. Lozin E.V. Abyssal structure and oil and gas content of the VolgoUral area and adjoining territories. Lithosphere, 2002, no. 3, pp. 46-68. In Rus.

16. Sulima A.I. Novye dannye o geologicheskom stroenii neftegazonosnosti yugo-vostochnykh territoriy Permskogo kraya [New data on the geological structure and oil and gas content of the southeastern territories of the Perm region]. Materialy Vserossiyskoy nauchno-prakticheskoy konferentsii, posvyashchennoy 100-letiyu so dnya rozhdeniya professora P.A. Sofronitskogo. Geologiya i neftegazonosnost severnykh rayonov Uralo-Povolzhya [Materials of the All-Russian scientific-practical conference dedicated to the $100^{\text {th }}$ anniversary of the birth of
Professor P.A. Sofronitsky. Geology and oil and gas content of the northern regions of the Ural-Volga region]. Perm, Perm State University Publ., 2010. pp. 270-275.

17. Read J. Carbonate platform facies models. AAPG Bulletin, 1985, no. 69 , pp. $1-21$.

18. Liang X., Jin Z., Philippov V., Obryadchikov O., Zhong D., Liu Q., Uspensky B., Morozov V.P. Sedimentary characteristics and evolution of Domanik facies from the Devonian-Carboniferous regression in the southern Volga-Ural Basin. Marine and Petroleum Geology, 2020, no. 119, pp. 1-12.

19. Sayago J., Di Luccia M., Mutti M., Sitta A., Cotti A., Frijia G. Late Paleozoic seismic sequence stratigraphy and paleogeography of the paleo-Loppa High in the Norwegian Barents Sea. Marine and Petroleum Geology, 1997, vol. 97, pp. 192-208.

20. Burchette T., Wright V. Carbonate ramp depositional systems. Sedimentary Geology, 1992, no. 79, pp. 3-57.

21. Lucia M., Sayago J., Frijia G., Cotti A., Sitta A., Mutti M. Facies and seismic analysis of the Late Carboniferous-Early Permian Finnmark carbonate platform (southern Norwegian Barents Sea): An assessment of the carbonate factories and depositional geometries. Marine and Petroleum Geology, 2017, no. 79, pp. 372-393.

22. Dott R. An introduction to the Ups and Downs of Eustasy. Eustasy: The Histroical Ups and Downs of a Major Geological Concept. Boulder. Geological Society of America Bulletin, 1992, vol. 1, no. 80. pp. 1-16.

23. Hallam A. Phanerozoic Sea-Level Changes. New York, Columbia University Press, 1992. 266 p.

24. Ruban, D. A «chaos» of Phanerozoic eustatic curves. Journal of African Earth Sciences, 2016, no. 116, pp. 225-232.

25. Henkes G., Passey B., Grossman E., Shenton B.J., Yancey T., Pérez-Huerta A. Temperature evolution and the oxygen isotope composition of Phanerozoic oceans from carbonate clumped isotope thermometry. Earth and Planetary Science Letters, 2018, no. 490 , pp. $40-50$

26. Boulila S. Coupling between Grand cycles and Events in Earth's climate during the past 115 million years. Scientific Reports, 2019, no. 9 , pp. 1-7.

27. Song H., Wignall P., Song H., Dai X., Chu D. Seawater Temperature and Dissolved Oxygen over the Past 500 Million Years. Journal of Earth Science, 2019, no. 30, pp. 236-243.

28. Cao W., Flament N., Zahirovic S., Williams S.E., Muller R.D. The interplay of dynamic topography and eustasy on continental flooding in the late Paleozoic. Tectonophysics, 2019, no. 761, pp. 108-121.

29. Kabanov P., Jiang C. Photic-zone euxinia and anoxic events in a Middle-Late Devonian shelfal sea of Panthalassan continental margin, NW Canada: Changing paradigm of Devonian ocean and sea level fluctuations. Global and Planetary Change, 2020, no. 188 , pp. $1-19$.

30. Snedden J.W., Liu C. A compilation of Phanerozoic sea level change, coastal onlaps, and recommended sequence designations. American Association of Petroleum Geologists Search and Discovery Article, 2010, 3 p.

Received 28 October 2021.

\section{Information about the authors}

Aleksandr I. Sulima, applicant, Perm State National Research University.

Aleksey V. Plyusnin, sedimentologist, LLC «INK».

Lev D. Pleshkov, senior lecturer, Perm State National Research University.

Yaroslav S. Trubin, research assistant, laboratory of sedimentology and evolution of paleobiosphere, Tyumen State University.

Vladislav D. Timofeev, applicant, Perm State National Research University. 